PAGES International Project Office Bärenplatz 2

$\mathrm{CH}-3011$ Bern

Switzerland

Tel: +41313123133

Fax: +41313123168

pages@pages.unibe.ch

Layout: Christoph Kull

Circulation: 3200

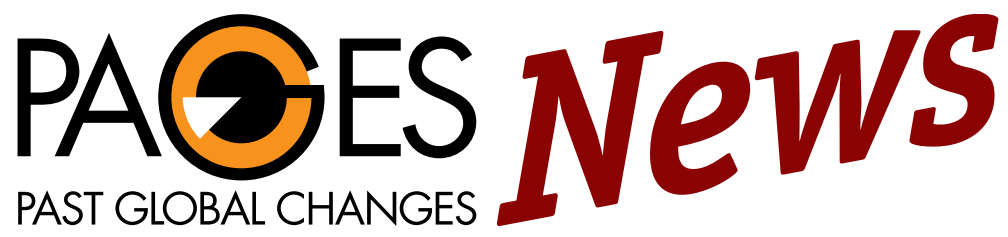

Christoph Kull

Mel Reasoner and Keith Alverson, Editors

Vol.9, $\mathbf{N}^{\circ} 3$ - DeC. 2001

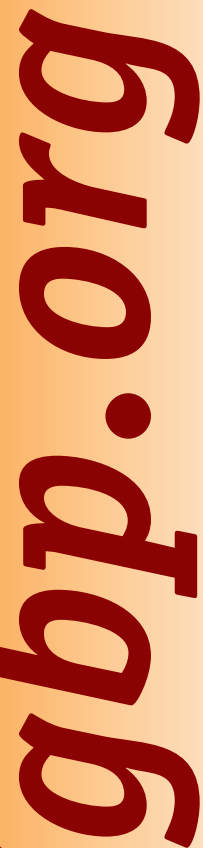

O

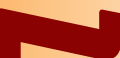
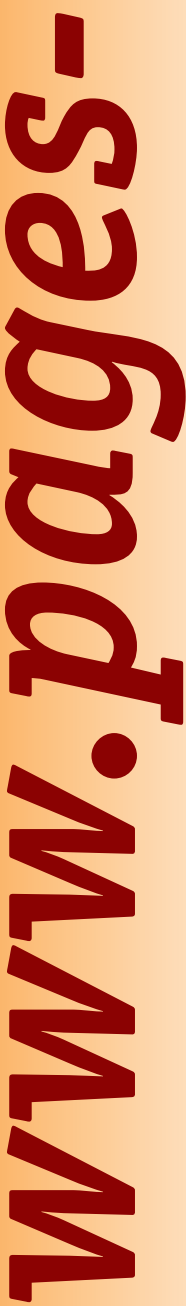

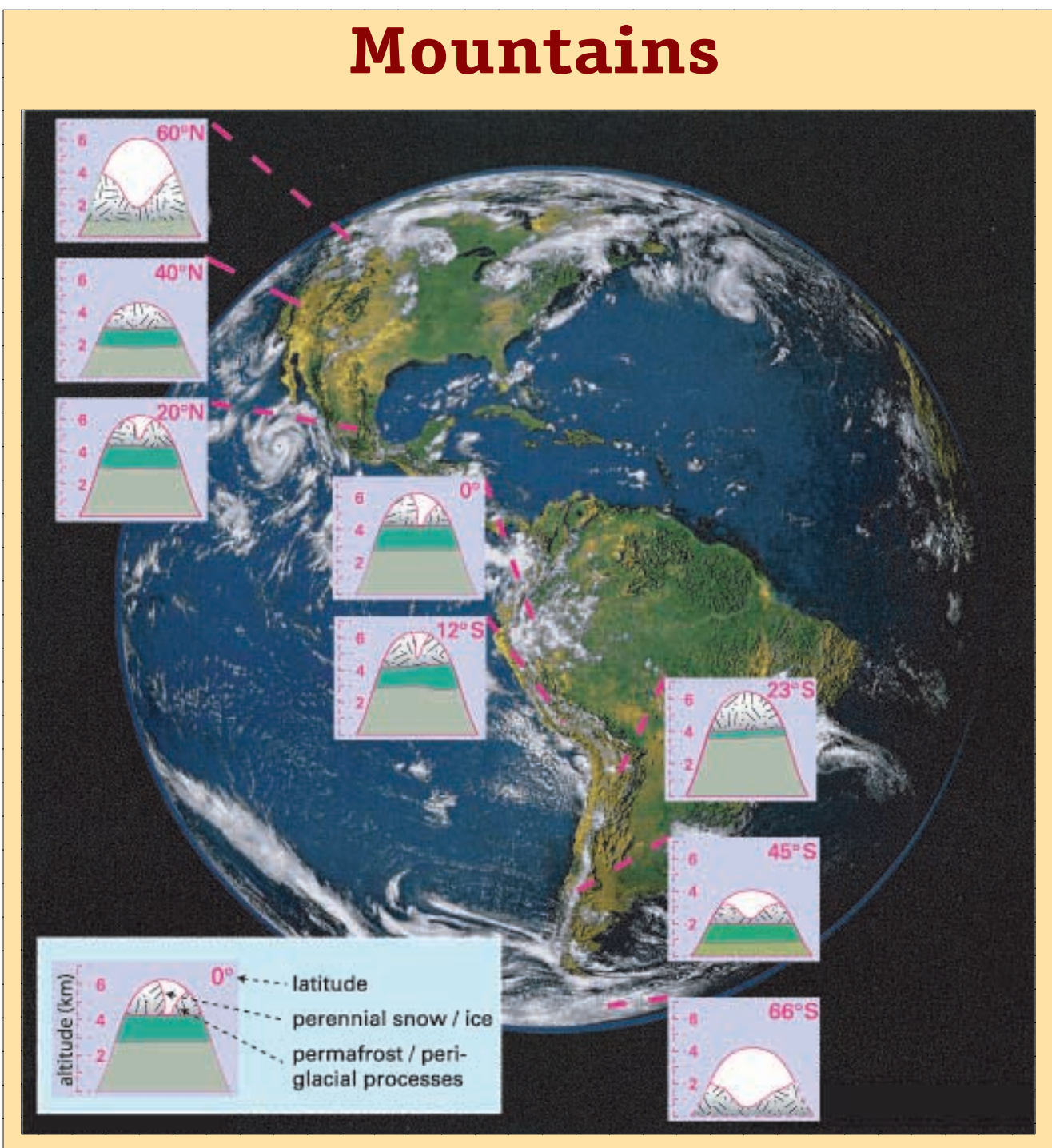

The uppermost mountain-ecosystems provide with their global uniformity a unique opportunity to study and compare effects of climate change in different regions of the world. This makes high-mountain areas a key to understanding forcing mechanisms, magnitudes and patterns of past and recent climate change.

\title{
Contents
}

2 Announcements

- Editorial: International Year

of the Mountains 2002

- PAGES-Conference, Inside PAGES

4 Program News

- The Mountain Research Initiative (MRI)

7 Science Highlights

- Alpine Speleothems

- Alpine Timberline

- Paleoenvironments in the Pirin and Altai
- A Himalayan Ice Core Record

- Treelines in the Americas

- East African Mountain-Paleoecology

22 Workshop Reports

- St. Petersburg (Baltic Holocene Climate)

- Aix-en-Provence (PEP-III)

- Have you seen

24 Last Page

- Calendar

- START Young Scientist awards 


\section{Editorial \\ The International Year of Mountains (IYM), the Mountain Research Initiative (MRI) and PAGES}

The special Mountain Chapter in the Agenda 21, "Managing Fragile Ecosystems - Mountain Sustainable Development," was universally accepted in the Rio conference 1992. However, prior to the special UN General Assembly for the evaluation of Agenda 21 in 1997, most of the new initiatives and activities came from NGOs and aid organisations and only after 1997 did the scientific community begin to realize its responsibility. It would be unfortunate if the contribution of science and research in the conference Rio+10 in Johannesburg 2002 and in the various mountain meetings scheduled for IYM 2002 is less than substantial.

A milestone is certainly the foundation of the MRI, which became active on July 1 st, 2001. As outlined by this initiative, future progress of Global Change Research in mountain regions will be enhanced by the establishment of linkages between mountain research projects in the different IGBP and IHDP programmes and by cooperation of these programmes with the GTOS special mountain module. Accordingly, the aim of the MRI is to facilitate the creation of initiatives, synergies and interdisciplinary projects that are necessary in order to effectively coordinate and integrate findings for the various aspects of climate change research in mountains, resources and resource management strategies, human impact studies on fragile ecosystems and, in particular, interactions between the natural and human driving forces.

As we pursue these new initiatives, we should not forget that research on mountain ecosystems has a long tradition. Alexander von Humboldt was conducting his initial field work on Chimborazo $(6310 \mathrm{~m})$ in Ecuadors's volcano valley in the year 1802 - exactly 200 years before the IYM 2002! His subsequent studies documented the highly differentiated ecosystems in several other mountain systems of the world. He ultimately compared the glaciation, vegetation and climatic conditions in an extraordinary overview publication "Atlas to Alexander von Humboldt's Kosmos". Figure 1 shows this memorable summary representing all the local, place-based research findings integrated in a global comparison. As exemplified on the cover of this issue and in Fig.1, the fact that mountain areas are, and have been in the geologic past, sensitive indicators of Global Change has long been appreciated by paleo-scientists. In recent decades, mountain regions have been recognized for their important archives of climate variability spanning different spatial and temporal scales. Such records include treerings, sedimentary records from high mountain lakes, permafrost, and in particular, evidence from glaciers. Further, the only ecosystem with worldwide distribution, which is comparable over all the different climatic zones of our planet, is the uppermost alpine belt above the treeline. This alpine zone is characterized by glaciers, snow cover, permafrost and periglacial processes, and alpine tundra vegetation. Paleoenvironmental records from this zone provide an excellent opportunity to compare records from climatically sensitive sites along a 'real' Pole-Equator-Pole transect such as the Cordillera of the Americas (front cover).

The IGBP has published an outlook to the future research decade in Global Change, which underscores several issues that are important to consider for the IYM. Priorities are given to three topics: the carbon cycle, water resources and food security and it is clear that mountain regions are of central importance to these three issues. Changes in the carbon cycle, particularly those associated with atmospheric $\mathrm{CO}_{2}$, have a profound impact on sensitive mountain ecosystems. Limited water resources will play a crucial role in the $21^{\text {st }}$ Century. In the arid and semi-arid regions of the tropics and subtropics, more than $80 \%$ or $90 \%$ of the fresh water supply originates in mountain areas and this may concern more than half of humanity, especially the developing world. Considering that $60-70 \%$ of the earth's available fresh water is used for food production, the significance of mountains for the third IGBP priority is absolutely clear. It is therefore crucial that the scientific community assumes responsibility for providing a much better understanding of mountain ecosystem function, conservation and development and the role of paleosciences in this effort will be key: The present without the past has no future!

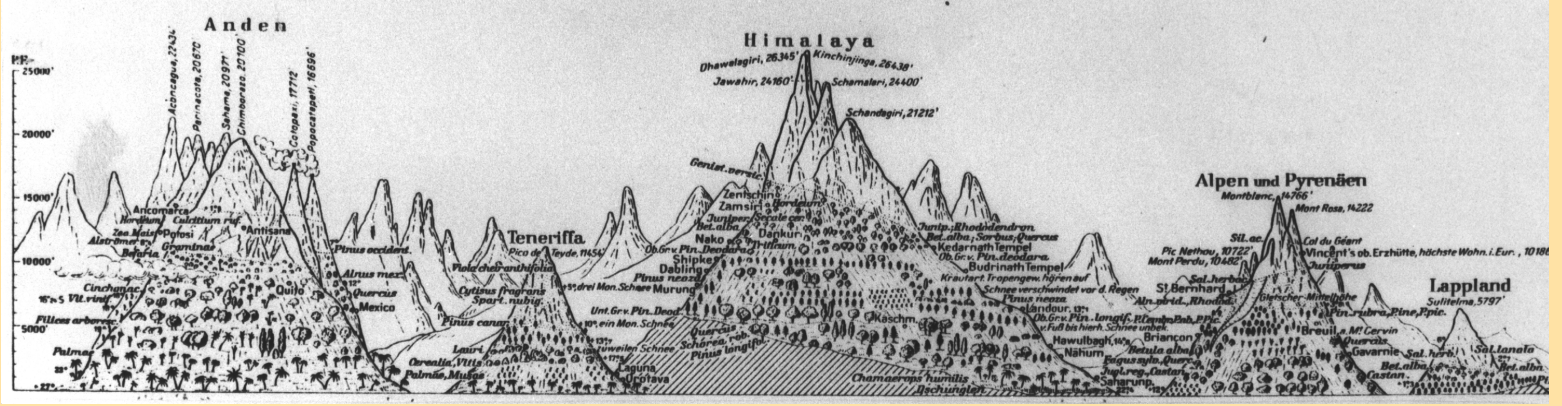

Fig. 1: Dominant vegetation zones in selected mountain systems. Altitude in feet. ("Atlas zu Alexander von Humboldt Kosmos," hrsg. von Traugott Bromme, Stuttgart 1851). After Troll, 1961, Erdkunde

Bruno Messerli 


\section{Announcements}

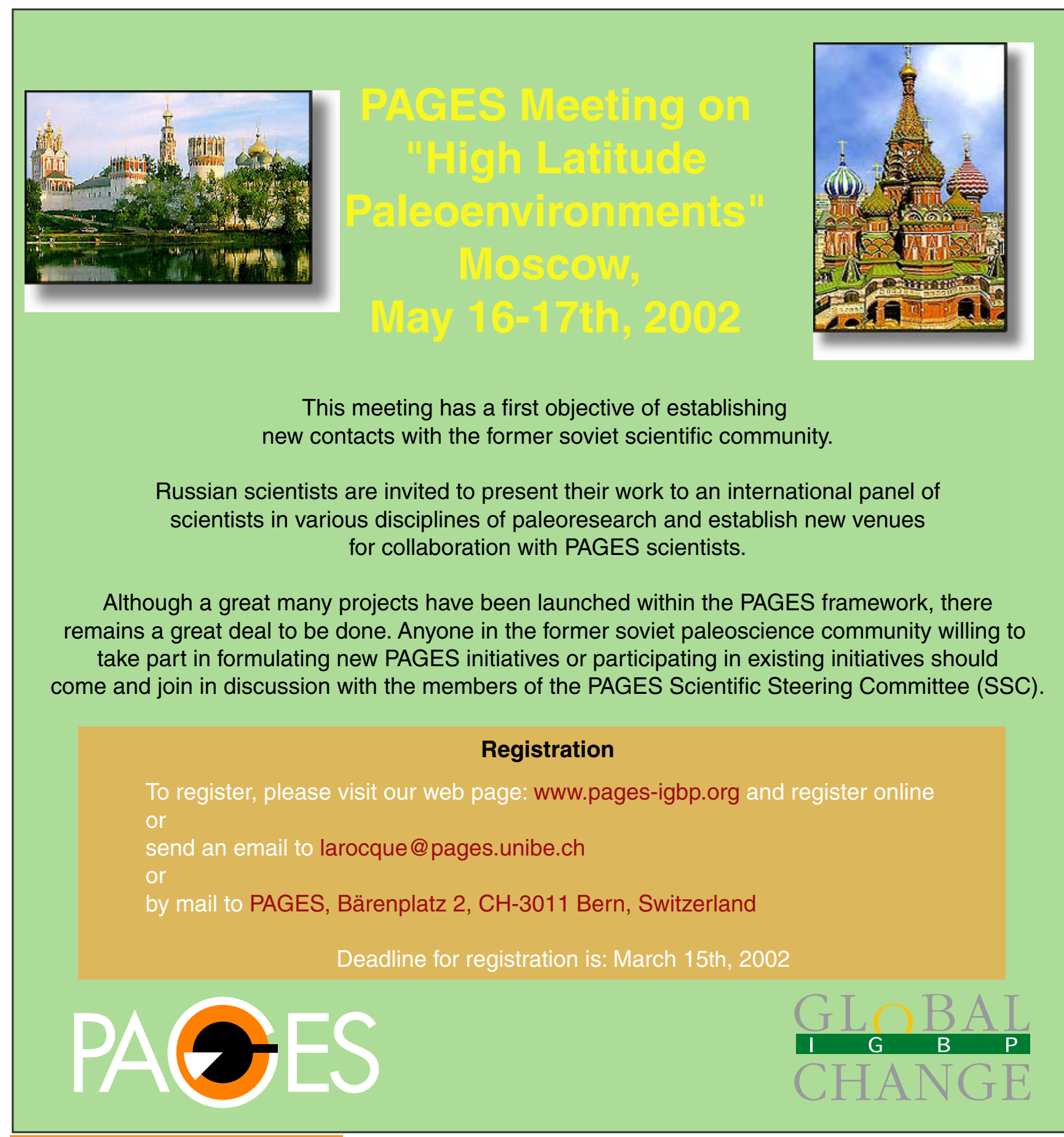

\section{Inside PAGES}

PAGES welcomes our new Office Manager, Selma Ghoneim, who began a $30 \%$ position in September. In addition to managing PAGES accounts and the logstics associated with PAGES activities, Selma is keen to learn about web publishing. Beginning in January, PAGES will host a sabattical visit by Tom Edwards from the University of Waterloo, Canada. Tom will be working to better integrate the use of stable isotopes in PAGES activities. In particular, he will facilitate a better integration of modern measurements of isotopes in precipitation as a means of calibrating past records. Tom is the PAGES representative on the WCRP and IAEA sponsored Global Network for Isotopes in Precipitation (GNIP) commitee.

\section{Call for Contributions:}

The next issue of PAGES News will highlight dendrochronology. Science highlights that fit within this theme, as well as the usual workshop reports and program news, are welcome. If you are interested in contributing to this issue please contact Isabelle Larocque (larocque@pages.unibe.ch). All submissions should follow the instructions for authors on our web-site and be submitted by January 31 , 2002.

www.pages.unibe.ch/products/ newsletters.html 


\section{The Mountain Research Initiative and Past Global Changes}

Mel Reasoner 1 , Alfred Becker ${ }^{2}$, Harald Bugmann 3 , Lisa Graumlich ${ }^{4}$, Wilfried Haeberli 5 Bruno Messerli 6 and Frank 0ldfield 7

1 MRI Coordination Office, Bärenplatz 2 CH-3011 Bern, Switzerland, reasoner@sanw.unibe.ch

2 Potsdam Institute for Climate Impact Research, 14412 Potsdam, Germany, becker@pik-potsdam.de

3 Gebirgswaldökologie, ETH-Zentrum, 8092 Zürich, Switzerland, bugmann@fowi.ethz.ch

4 Mountain Research Center, Montana State University, Bozeman, MT 59717-3490 USA, lisa@montana.edu

5 Geographisches Institut, Universität Zürich, Zollikerstr. 107, 8008 Zürich, Switzerland, haeberli@geo.unizh.ch

6 Geographisches Institut, Hallerstrasse 12, University of Bern, CH-3012 Bern, Switzerland, messerli@giub.unibe.ch

7 PAGES, West Kirby, Wirral CH 48 2HF, UK, f.oldfield@btinternet.com

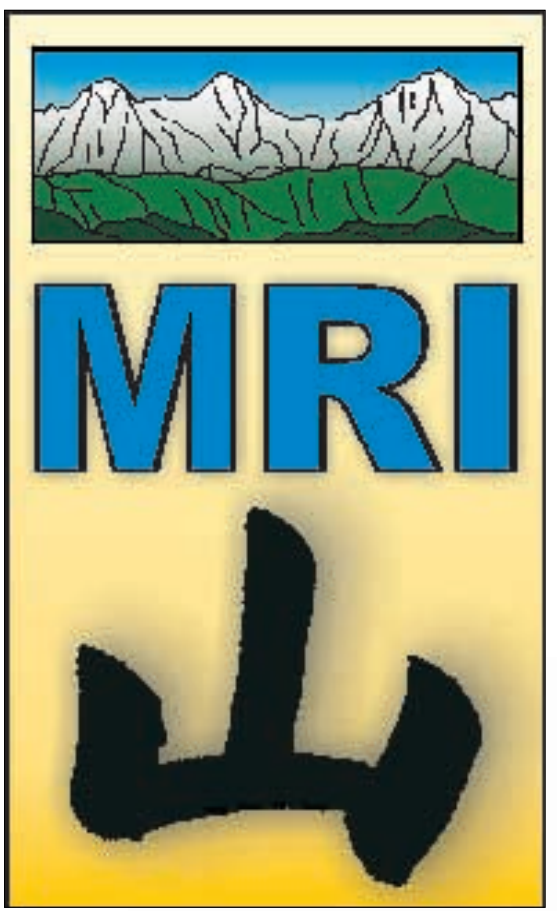

In order to address the consequences of global change in mountain regions, an initiative for collaborative research on global change and mountain regions - the Mountain Research Initiative (MRI) - was developed and officially launched in July, 2001. This initiative formulates and coordinates an integrated, multidisciplinary approach to observing, modeling and investigating global change phenomena and processes in mountain regions, including impacts on ecosystems and socio-economic systems (Fig. 1). The MRI has been formally endorsed by the International Human Dimensions Programme on Global Environmental Change $(\mathrm{IH}-$ DP), Global Terrestrial Observing System (GTOS) and the four core projects of the International Geosphere-Biosphere Programme (IGBP): PAGES, Global Change and Terrestrial Ecosystems (GCTE), Biospheric Aspects of the Hydrological Cycle (BAHC) and Land-Use and Land-Cover Change (LUCC).

Collaboration with PAGES activities will form an integral part of the overall structure of the MRI program. Understanding the presentday and future status of mountain systems such as glaciers, terrestrial ecosystems, and permafrost requires a detailed knowledge of the natural environmental variability that prevailed prior to anthropogenic forcing. Studies of past environmental change in mountains are extremely important and valuable in this context due to the inherent climatic sensitivity of mountain ecosystems. Further, processes such as climatic forcing and ecosystem dynamics operate and interact on a wide range of time scales, from individual extreme events to century- and millennial-scale variability to glacial cycles. Documenting process dynamics on all of these time scales will require a diversity of methods and archives.

From a scientific point of view, the altitudinal gradients in mountain regions provide unique opportunities to detect and analyze global change processes and phenomena because meteorological, hydrological, cryospheric and ecological conditions change markedly over relatively short distances. Accordingly, biodiversity tends to be high, and characteristic sequences of ecosystems and cryospheric systems are found along mountain slopes. The boundaries between these systems (e.g. ecotones, snowline, glacier boundaries) may experience rapid shifts due to environmental change. The higher parts of many mountain ranges are not affected by direct human activities and may serve as locations where the environmental impacts of climate change alone, including changes in atmospheric chemistry, can be studied. Mountain regions are distributed all over the globe,

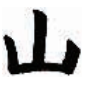
This is the Chinese character for mountain from the Equator almost to the poles and from oceanic to highly continental climates. This global distribution provides opportunities to carry out comparative regional studies from widely separated parts of the globe and to analyze the regional differentiation of environmental change processes.

The ultimate objectives of the MRI are:

1) To develop a strategy for detecting signals of global environmental change in mountain environments. The emphasis of the first objective is on monitoring change in the biophysical environment, and on understanding the interacting ecological and hydrological processes in mountain regions, both with and without local human interference, along altitudinal and other gradients (e.g. land use). Such work recognizes the unique value of many mountain ecosystems that have been and remain relatively uninfluenced by direct human activities, especially in protected areas such as parks and biosphere reserves. An important aim of this objective is to develop a network of observation sites in mountains to serve as an 'early warning' system for detecting global change impacts.

2) To define the consequences of global environmental change for mountain regions as well as lowland systems dependent on mountain resources (highland-lowland interactions). The emphasis of this objective is to increase our understanding of the consequences of global environmental change for people and ecosystems. Credible impact assessments form the baseline for informing policymakers on issues of global environmental changes at local to global levels. In addition, information from impact assessments has direct application to policies and strategies 
for resource management that are implemented at local and regional scales.

3) To facilitate sustainable land, water, and resource management for mountain regions. The emphasis of the third objective, initiating sustainable development strategies, is to define a set of potential human responses to global environmental change that can be implemented at local and regional scales. Scientific results developed under this objective will assist policymakers by indicating the extent of degradation of key mountain resources, and by evaluating interactions between alternative resource management strategies and trajectories of change generated by global factors.

To achieve the above objectives, the research under the MRI is structured around four activities, each of which is divided into a small number of specific tasks.

\section{Activity 1: \\ Monitoring and Analysis}

This element of the Initiative will focus on mountain-specific indicators of environmental change, which are sensitive to changes in climate, atmospheric chemistry, radiation, and land use/land cover. A set of four mountain-specific indicator groups is considered:

1.1) Cryospheric indicators related to snow conditions, glaciers, permafrost and solifluction processes:

1.2) Terrestrial ecosystems, particularly mountain plant communities and soils;

1.3) Freshwater ecosystems, in particular high mountain streams and lakes; and

1.4) Watershed hydrology, i.e. water balance components of high mountain watersheds/headwater basins.

Contemporary monitoring will be arranged within the context of reconstructions of longer-term past trends and variability. Therefore, it is crucial that new monitoring sites in different mountain regions are located at or near sites where historical and paleorecords can be made available, so that the results from

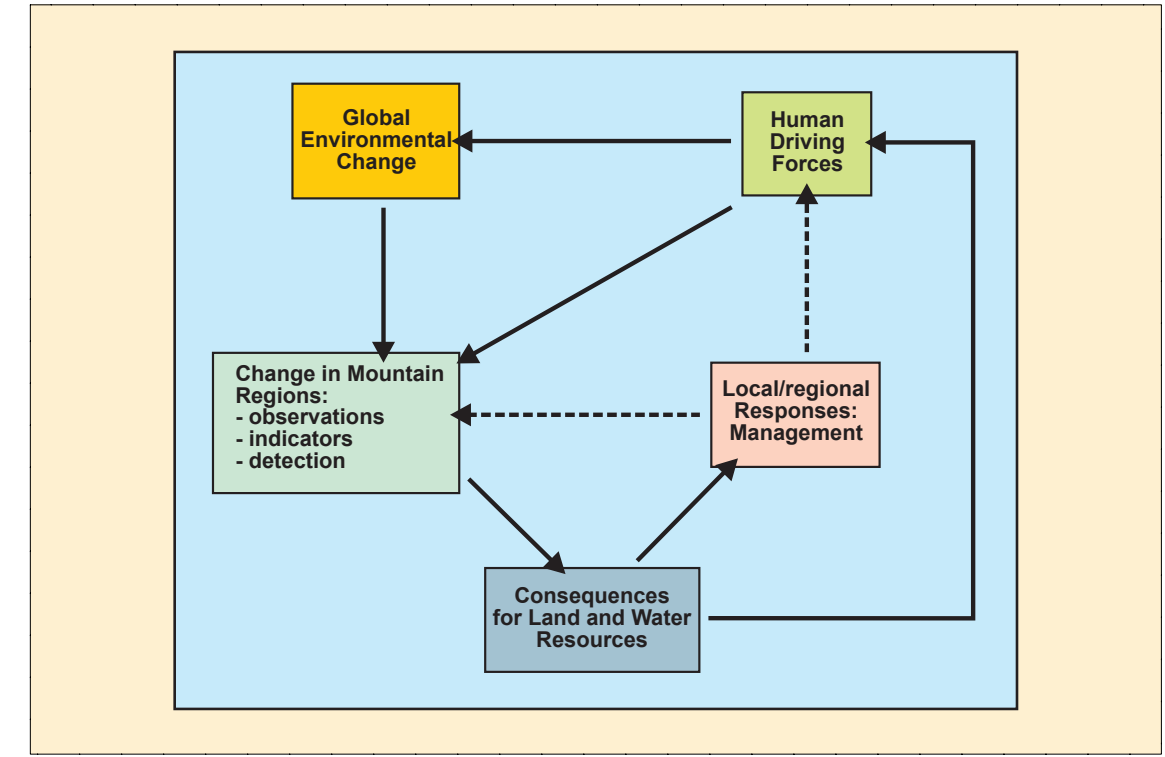

Fig. 1: Conceptual framework for the integrated study of global environmental change in mountains, emphasising feedbacks that occur both within a given mountain region (inner loops) as well as at the global scale (outer loop).

recent observations and research can be related directly to past variability. Paleorecords in general will be used to reconstruct past dynamics of climatic, hydrological and ecological conditions. Most important in this context are:

a) paleoecological reconstructions based on pollen, diatom, fossil pigment and macrofossil (including arthropod) profiles from lakes and mires;

b) lake studies, via reconstructions of flood related sedimentation layers, shore-line fluctuations and both temperature and salinitylinked biotic variations in the sediment record;

c) analysis of cores taken from ice, snow and even permafrost, in particular those providing information on fluctuations in the amount and sources (e.g. using stable isotopes) of past precipitation in mountain regions;

d) dating of geomorphic features associated with past climate change (e.g. moraines) and

e) tree ring analyses in regions where either moisture availability or temperature was the dominant stress on tree growth.

\section{Activity 2: Integrated modeling}

To achieve the overall goals of the initiative, it is necessary to develop a framework that permits the analysis and prediction of hydrological and ecological characteristics and their linkages with land use and climate. Accordingly, this activity is organized around the following:

2.1) Development of coupled ecological, hydrological and land use models for the simulation of land cover and land surface processes in complex mountain landscapes;

2.2) Development of high resolution regional scale atmospheric models for mountain regions;

2.3) Integrated analysis of environmental change in mountain regions by means of fully coupled land-atmosphere models; and

2.4) Regional scale mountain land process experiments complementing modeling efforts.

The modeling activities proposed here require close coordination with the long-term monitoring and process studies conducted under Activities 1 and 3, including reconstructions of past environmental dynamics from paleorecords. The potential for the development of fully coupled land-atmosphere models for mountain regions is particularly exciting. These models could prove very useful for predicting the effects of land use/land cover and climate changes on spatial scales appropriate for the investigation of global change in mountain regions. The predictive utility of these models, however, will only be robust if they are validated with paleoenvironmental records from sensitive 


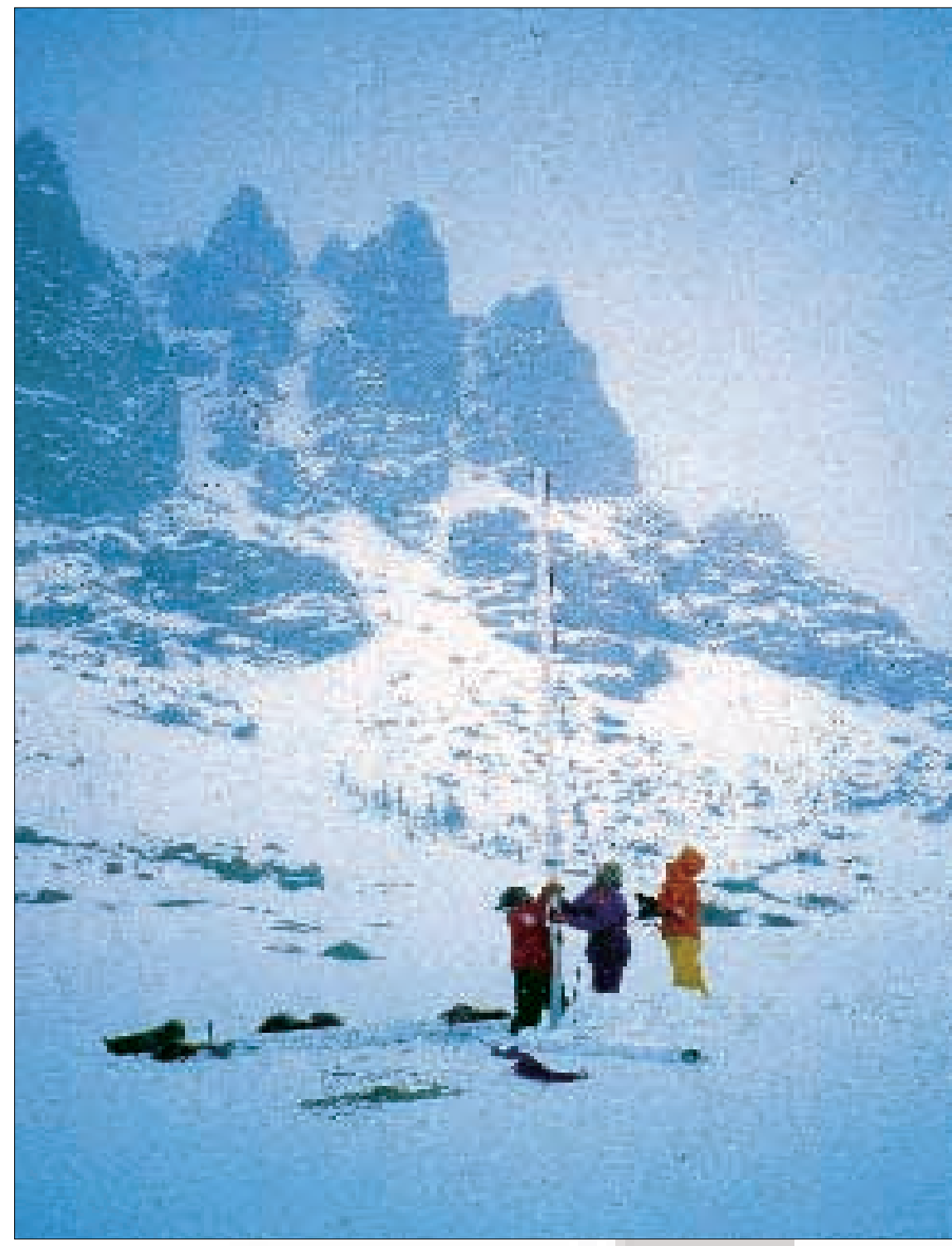

Fig. 2: A lightweight percussion coring system designed for remote access being used to recover a continuous 14,000-year lake sediment record from Sky Pond (3320 $\mathrm{m}$ asl) in the Colorado Front Range. The Sky Pond record provides the first clear indication that changes in late-glacial and early Holocene vegetation near timberline in the Rocky Mountains were in phase with the Younger Dryas climatic oscillation in the North Atlantic region. Additional paleo records from climatically sensitive high elevation sites are required from mountain regions around the world to complete the picture of regional paleoenvironmental changes.

terrestrial sites. Mountain regions provide excellent opportunities for the acquisition of such information.

\section{Activity 3: Process Studies}

Ecological and hydrological field studies and experiments along altitudinal gradients and at sensitive sites can provide invaluable data on potential responses of mountain ecosystems to anthropogenically induced environmental change. Research themes to be addressed within this Activity include:

3.1) Development of indicators of mountain ecosystem response to environmental forcing factors to fa-

\section{Activity 4:}

\section{Resources Management}

The overall objective of this Initiative is to evaluate and enhance sustainable land, water, and resource management strategies for mountain regions. Three priority areas are suggested for assessment:

4.1) Changes in forest resources, with potential implications for agriculture, rates of erosion and magnitude of floods, and biodiversity;

4.2) Intensification and/or extensification of agriculture (including grazing), with potential implications for food security, rates of erosion and magnitude of floods, and biodiversity; and

4.3) Changes in water resources due to factors such as changing agricultural practices, increasing temporary or permanent population, and increasing energy generation, with implications for downstream water supply, energy availability, flooding, and sediment transfer.

From its inception, the MRI has acknowledged that PAGES activities must play a central role in the overall objectives of the Initiative. Researchers involved with reconstructing past environmental change have long recognized that mountain regions are often ideal locations for the study of past global change processes (Fig. 2). The other side of the coin is that their sensitivity renders mountain regions particularly vulnerable to the many anticipated changes of the $21^{\text {st }}$ Century. Understanding this vulnerability is extremely important for humankind considering the large number of people who may be directly and indirectly impacted by changes in mountain regions. Consequently, the development of credible scenarios for the management of mountain environments is an urgent priority. The MRI will contribute not only to the scientific understanding of ongoing processes of change, but will ultimately provide foundations for policies that act to preserve the ability of mountain regions to provide the goods and services on which humanity has come to depend. ies can be used to tie recent experimental and monitoring activities to sediment-based research. 


\section{Alpine Climate Changes as Reconstructed from Speleothems}

Silvia Frisia 1 and IAN FaIRChILd 2

1 Museo Tridentino di Scienze Naturali,Via Calepina 14, 38100 Trento, ITALY, frisia@mtsn.tn.it

2 School of Earth Sciences and Geography, Keele University, Staffs, UK, i.j.fairchild@keele.ac.uk

The use of $\delta^{18} \mathrm{O}$ signals from calcite is a major component of speleothem based climate reconstructions. However, the validity of these reconstructions depends on knowledge of the source water isotopic composition. The complex controls on source water composition in the modern climate were investigated during a four-year programme of monthly monitoring of meteoric water $\delta^{18} O_{p}$ along an E-W traverse in Trentino, South-Central Alps at stations from 180 to 2,200 meters above sea level. The monitoring indicates that the modern precipitation $\delta 180_{p}$ signal is influenced by 1 ) the $\delta^{18} \mathrm{O}_{\mathrm{p}}$ of the air masses from western and southern provenance, 2) the deviation of water vapor transport trajectories due to mountain ranges, and 3) the elevation effect, whereby moisture content in westerly air-masses, which cross $3,000 \mathrm{~m}$ mountain ranges, is more depleted than that in southerly air masses. For example, at the meteorological station set in the Brenta Dolomites (W-Trentino), mean annual $\delta^{18} \mathrm{O}_{\mathrm{p}}$ increases by as much as $1.5 \%$ when southern trajectories dominate over western trajectories.

Because past $\delta^{18} \mathrm{O}_{\mathrm{p}}$ may have varied considerably as a consequence of circulation changes, it is not possible to construct a simple transfer-function for the Holocene, relating the oxygen isotopic composition of speleothem calcite $\left(\delta^{18} O_{c}\right)$ to mean air temperature. It is, therefore, difficult to reconstruct Holocene temperature and rainfall history in the Alps from oxygen isotope profiles of speleothem calcite alone. Current research on Holocene climate change in the Southern Alps focuses on analysis of multiple, independent, annual-resolution proxies within a given speleothem and their relationships to climate parameters. In addition, several stalagmites are generally sampled from different nearby caves.

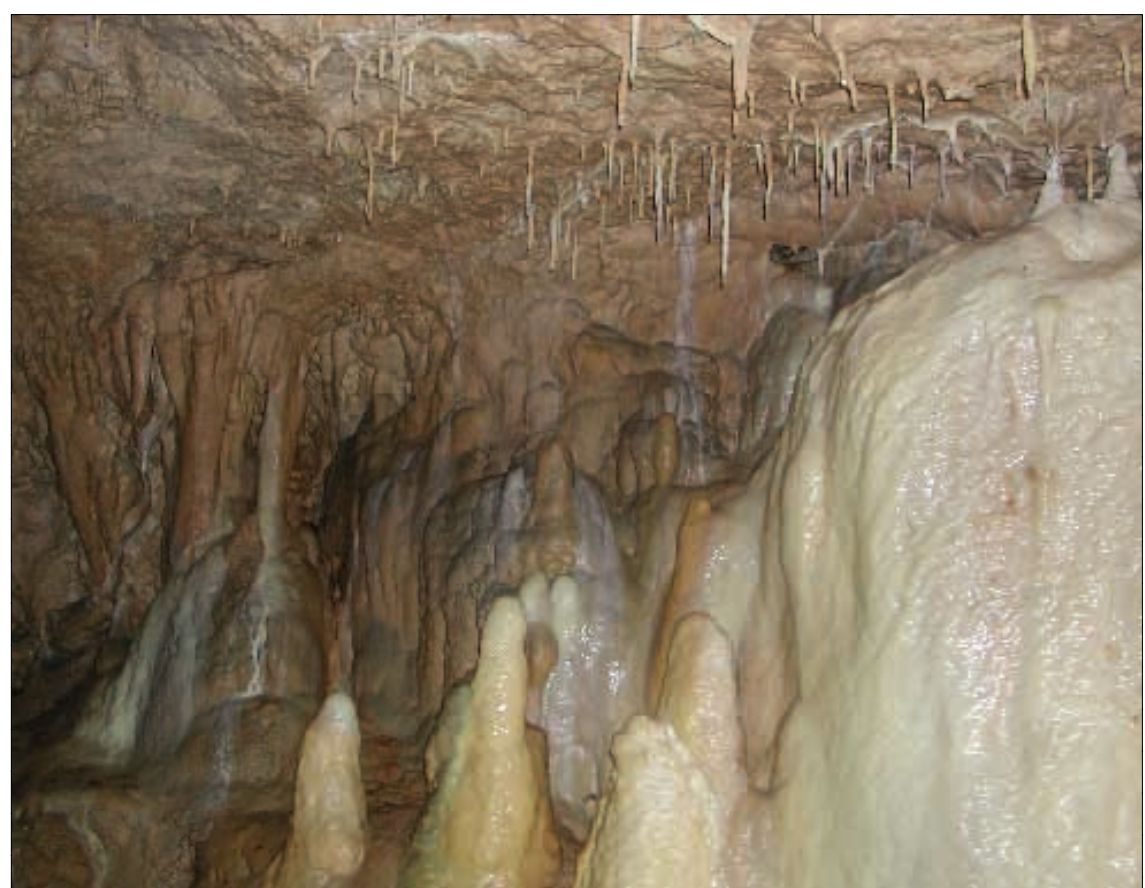

Fig. 1: Grotta di Ernesto (Trentino, Northern Italy). Active stalagmites, which are being monitored for modern seasonal crystal growth and dripwater parameter analyses, and sampled for paleoreconstructions.

For example, at Grotta di Ernesto, at 1,160 meters above sea level (Fig. 1), paleoclimate research has been carried out for the past 6 years. High-resolution, alpine climate and environmental reconstruction from stalagmites has been obtained through the comparison of a $\delta^{18} \mathrm{O}_{\mathrm{c}}, \delta^{13} \mathrm{C}_{\mathrm{c}}, \mathrm{Mg} / \mathrm{Ca}$ ratio and calcite fabric series dated by TIMS U/Th (Fig. 2). Each of these proxy indicators has either a different sensitivity to the same environmental process or records processes which are not registered by the other proxies. In particular, calcite fabrics in shallow subsurface caves such as Grotta di Ernesto are very sensitive to climate-related fluctuations in water availability, seasonal flow changes, and the presence of growth-poisoning particles (or dissolved ions) in dripwater. Comparison of the four proxy data series, combined with the information from the monitoring of modern day precipitation, allows an interpretation of major trends in the Holocene $\delta^{18} \mathrm{O}_{\mathrm{c}}$ profile in terms of regional circulation changes. Figure 2 shows Holocene profiles of four climate proxy indicators loxygen and carbon stable isotopes, $\mathrm{Mg} / \mathrm{Ca}$ ratio and fabrics) for stalagmite $E R$ 76 from the Southern-Central Alps of Italy.

\section{Mid Holocene Climate}

The most humid period in these records occurred around 7,600 yr BP. This period is indicated by low $\mathrm{Mg} / \mathrm{Ca}$ ratio and low $\delta^{18} \mathrm{O}_{\mathrm{c}}$ values. $\delta^{13} C_{C}$ is also low at this time, sugled to increased soil $\mathrm{CO}_{2}$ production. During this humid period from 8,000 to $7,000 \mathrm{yr} B P$, high mountain human settlement sites were abandoned, and agriculture was introduced in the valleys of Trentino.

The 6,700 to 6,570 yr BP interval was probably a relatively warm period. During this time, mean annual $\delta^{18} \mathrm{O}_{\mathrm{w}}$ of precipitation was less depleted (only by about $-0.5 \%$ ) with respect to the present values than is the case for most of the early to mid Holocene, and stalagmite $\delta^{18} \mathrm{O}_{\mathrm{c}}$ was only -0.2 to $-0.4 \%$ o depleted relative to the present value. This period is also marked by glagesting that moisture availability 


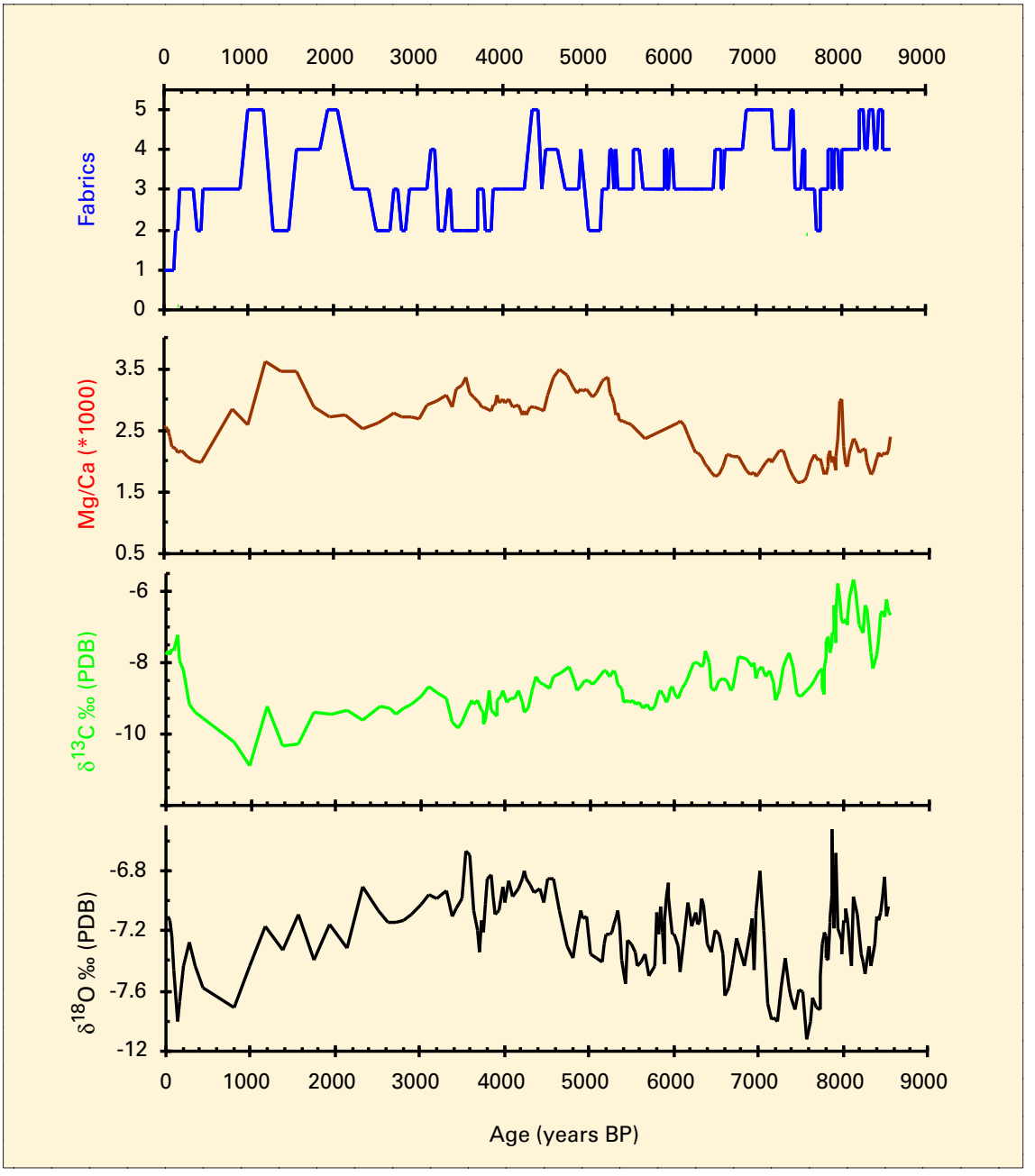

Fig. 2: Holocene profiles of four climate proxy indicators loxygen and carbon stable isotopes, Mg/Ca ratio and fabrics) for stalagmite ER 76 from the Southern-Central Alps of Italy. Fabric numbers correspond to: 1) columnar; 2) columnar to microcrystalline, 3) microcrystalline, 4) microcrystalline to dendritic and 5) dendritic (see Frisia et al., 2000 for details).

cial retreat in the Central Swiss Alps (Hormes et al., 2001).

All of the speleothem proxies record a change in the moisture balance in the Southern Alps starting at 5,400 $\mathrm{yr}$ BP. This change affected vegetation $\left(\delta^{13} C_{c}\right)$, the residence time of the water in the aquifer (Mg/Ca ratio), seasonal variability in physico-chemical parameters (fabrics) and precipitation isotopic composition $\left(\delta^{18} O_{c}\right)$. The change probably involved a change in air mass trajectories causing additional 180-enriched moisture to be advected into the Southern Alps. If the analogy with today's air circulation patterns holds true, it is possible that southern trajectories were predominant over western trajectories from around 5,200 to 2,400 yr $\mathrm{BP}$. This long and relatively dry period corresponds to prolonged glacier minima in the Central Swiss
Alps (Hormes et al., 2001), and had important societal implications. Archaeological data indicate that the practice of high alpine pasturage began around 5,500-5,200 yr BP. There is also archaeological evidence that man and cattle crossed high alpine passes during this period. It is interesting to note that a major mid-Holocene event recorded by many paleodata, the 4,200 yr BP dry spell, is not recorded in the speleothem $\delta^{18} \mathrm{O}_{\mathrm{c}}$ profile, though it is recorded by a change to dendritic fabric between 4,400 and 4,200 yr BP.This fabric type is believed to develop under limited dripwater availability (Frisia et al. 2000).

\section{Late Holocene Climate}

The interpretation of the past 3800 years has to account for the strong anthropogenic modification of vegetation and, consequently, soil $\left(\delta^{13} C_{c}\right)$ as a result of enormous quantities of wood used in smelting activities in the Southern Alps. The decrease in stalagmite growth rates at Grotta di Ernesto at this time (McDermott et al. 1999) may be a consequence of human impact, rather than climate change. Subsequent to $3,800 \mathrm{yr} \mathrm{BP}$, the $\delta^{18} \mathrm{O}_{\mathrm{C}}$ profile tends toward values similar, or more depleted than, present-day values. The $\mathrm{Mg} / \mathrm{Ca}$ ratio curve, on the other hand, remains characterized by values higher than at present-day, indicating that the climate mode established around 5,200 yr BP persisted until around 2,400 yr BP. The dominant calcite fabric at this time is indicative of seasonal variability in dripwater flow and impurity content. However, because the stacking of crystallites is regular, there was less contrast between winter-spring and summer-autumn deposition (Frisia et al., 2000).

Holocene climate variability in the Alps had a profound impact on the environment and society. We believe that alpine speleothems paleodata provide a powerful tool for reconstructing this variability accurately and at high resolution. However interpretation of speleothem archives requires cross-correlation between multiple independent proxies. The interpretations described here will be improved by higher resolution studies and improved calibrations from modern process studies and climate parameters.

\section{ACKNOWLedGement:}

Helpful comments from Christoph Spötl have been greatly appreciated.

\section{REFERENCES}

Frisia, S., Borsato, A., Fairchild, I.J., \& McDermott,

F., (2000), Calcite fabrics, growth mechanisms, and environments of formation in speleothems from the Italian Alps and southwestern Ireland. Journal Sedimentary Research, 70, 1183-1196.

Hormes, A. Müller B. U Schluchter, C. 2001, The Alps with little ice: evidence for eight Holocene phases of reduced glacier extent in the Central Swiss Alps. The Holocene, 11, 255-265

McDermott F., Frisia S., Huang Y., Longinelli A., Spiro B., Heaton T.H.E., Hawkesworth C., Borsato A Keppens E., Fairchild I.J., Van der Borg K., Verheyden S., Selmo E., 1999, Holocene Climate variability in Europe: Evidence from $\delta^{18} 0$ and textural variations in speleothems, Quaternary Science Reviews, Vol 18, p. 1021-1038. 


\section{Science Highlights}

\section{Timberline Paleoecology in the Alps}

\section{Willy Tinner and Brigitta Ammann}

Institut für Pflanzenwissenschaften der Universität Bern, Berne, Switzerland, willy.tinner@ips.unibe.ch, brigitta.ammann@ips.unibe.ch

\section{Holocene Timberline Fluctuations and Climate Variability}

Alpine life and landscapes are exposed to extreme environmental conditions. Avalanches, landslides and floods, due to extreme climatic events such as heavy snow and rain storms, can impact both wild and managed landscapes. Above timberline, climatic conditions are so harsh that they impede the growth of trees. According to one recent hypothesis (the "growth-limitation hypothesis"), low temperatures reduce production of plant tissues (Körner, 1999). Therefore, trees become victims of their strategy to accumulate large amounts of biomass in order to overgrow other vegetational life forms. Because the upper boundary of tree growth is temperature controlled, it can be used as a proxy for estimation of past temperatures, assuming that today's occurrence of trees is in equilibrium with local climate. Similar assumptions are made to derive paleo-temperature estimations from other organisms. Many recent paleoecological studies in the Alps have focused on climate reconstruction, but relatively few studies have addressed basic past relationships between organisms and their biotic and abiotic environments. One of the reasons for avoiding the latter topic may be that accurate studies require independent environmental proxies and high temporal resolution (years to decades), especially if the goal is to reconstruct past responses of short-lived organisms to climatic change. Moreover, concerns about global warming have focused much effort on the reconstruction of past climatic changes and their forcing mechanisms, but the response of organisms and biomes seems - at least from an ecological and economical point of view - of similar relevance (e.g. collapse, migration or adaptation of boreal and alpine life).

The above-mentioned assumption that today's distribution of trees is in equilibrium with climate may not necessarily be true. Over the past several thousands years, human activities in the Alps have resulted in lowering of timberlines by 200-300 altitudinal meters. Nevertheless, single trees in remote

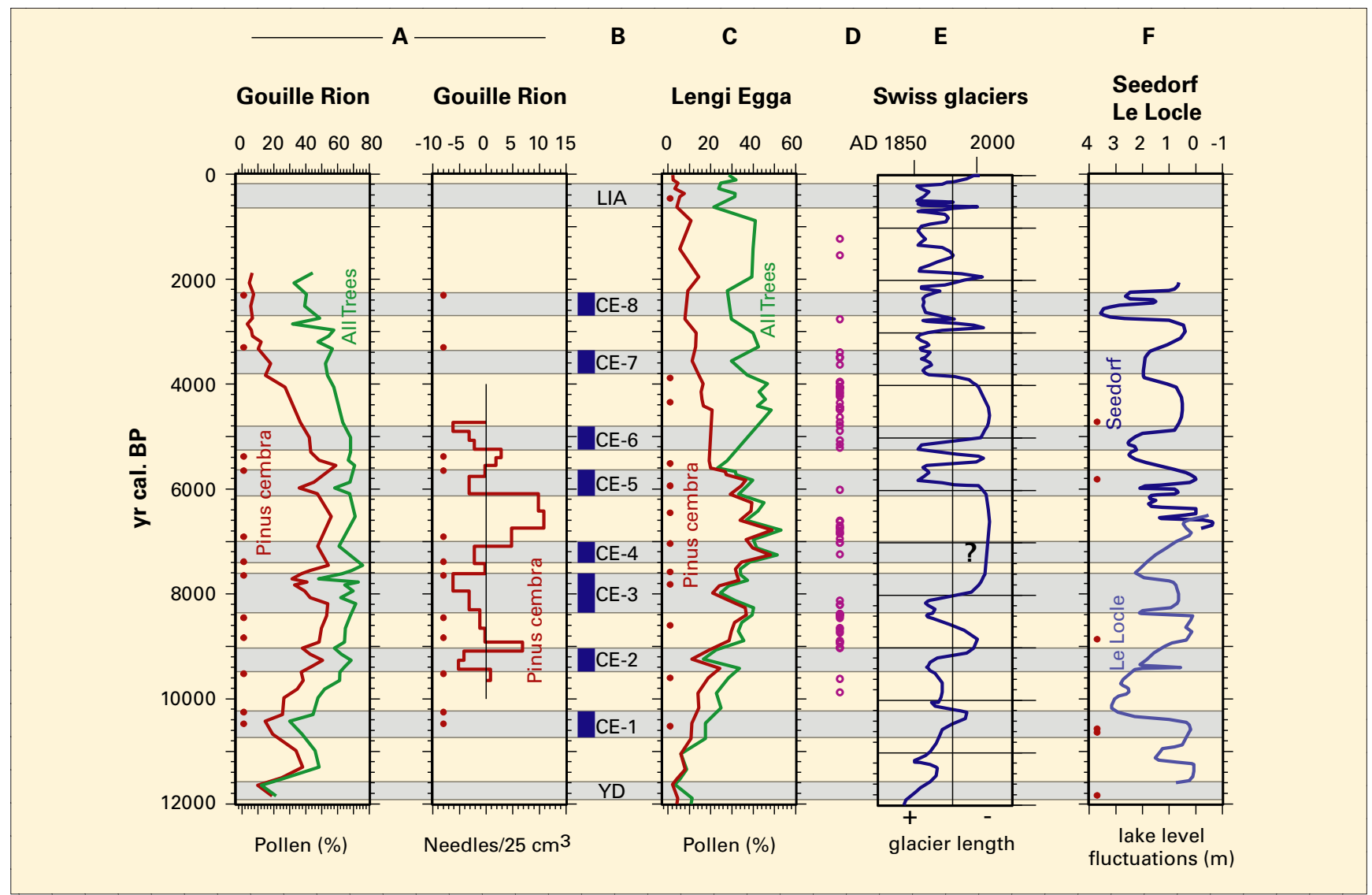

Fig. 1. Comparison between timberline vegetation, glaciers, and lake level fluctuations during the past 12,000 cal. yr BP. A: Pollen percentages (Pinus cembra, sum of trees) and macrofossil concentrations (Pinus cembra needles) at Gouillé Rion (Swiss Alps) (Tinner et al. 1996; Tinner and Wick, 1997). The pollen sum includes only subalpine and alpine taxa. B: Central European cold-humid phases (Haas et al. 1998). C. Pollen percentages (Pinus cembra, sum of trees) at Lengi Egga (Swiss Alps) (Tinner, unpublished). The pollen sum includes only subalpine and alpine taxa. D: Chronological position of radiocarbon dates of wood and organic debris collected in front of Alpine glaciers (Hormes et al., 2001). E: Estimated length variation of Swiss glaciers (Maisch et al., 1999). F: Lake level fluctuations in meters at Seedorf and Le Locle (Switzerland) (Magny and Richoz, 1998; Magny and Schoellammer, 1999). The dots in A, C, and F show the chronological position of radiocarbon dates used for the depth-age models. 
areas may still indicate the potential altitudinal limit of tree growth. Qualitative timberline-inferred temperature reconstructions in the Alps are based primarily on these uppermost survivors. No quantitative timberline-based temperature reconstructions are available for the Alps.

Producing qualitative Holocene temperature reconstructions requires records from today's timberline ecotone that reach back to the Late Glacial. Two factors are essential: 1)The chronology must be fixed to an absolute scale with sufficient ${ }^{14} \mathrm{C}$-dates and 2 ) terrestrial macrofossils must be present in high amounts throughout the Holocene to demonstrate the local presence of trees or alpine herbaceous species. One example is the Gouillé Rion site (Tinner et al., 1996), situated in the Central Swiss Alps and lying exactly at the limit of today's tree growth (trees > 5m; 2,343 m a.s.l.). Macrofossil analysis shows that the site was forested by coniferous species (Larix decidua, Pinus cembra) between 10,500 and 3,900 cal. yr BP indicating that during the early and middle Holocene growing season temperature was at least as high as today. Additional data from above today's tree limit indicate the uppermost limit of Holocene forest expansion and hence the range of Holocene temperature oscillations between 10,500 and 3,900 cal. yr BP (Tinner, unpubl.). Treeline was about 120-180 $\mathrm{m}$ higher than today in the warmest phases $(9,000-8,200$; 7,000-6,400; and 5,000-4,000 cal. $\mathrm{yr}$ BP.). Assuming a lapse rate of $0.7^{\circ} \mathrm{C} / 100 \mathrm{~m}$, this suggests summer temperatures about $0.8-1.2^{\circ} \mathrm{C}$ higher than today. Between 10,500 and 3,900 cal. yr BP, treeline was always situated above the modern limit. Hence, the range of temperature oscillations was limited to $0.8-1.2^{\circ} \mathrm{C}$ and never fell below today's values. This amplitude of Holocene temperature changes is confirmed by a quantitative chironomid-based study from the northern Alps (Heiri, 2001) (about $80 \mathrm{~km}$ away). Pinus cembra pollen declines at Gouillé Rion are strongly correlated with negative temperature excursions, as estimated by chironomid-based transfer functions. Moreover, the new study allows a reconstruction of temperature oscillations after 4,000 cal. yr BP, when timberline position was influenced by prehistoric land-use (and hence less reliable for climatic reconstructions). In Figure 1, oscillations of treeline are illustrated by declines in the curves (macrofossils and pollen) of both Pinus cembra and all subalpine trees. After the local extinction of Pinus cembra at around 4,000 cal. yr BP, cold phases are recorded by tree species growing 200-300 m below the former Pinus cembra belt (e.g. Picea abies).

A recent systematic redefinition of Holocene climatic fluctuations in the Alps was attempted by Haas et al. (1998). Based on paleoecological data (pollen, macrofossils, sedimentology) as well as ${ }^{14} \mathrm{C}$-dates, the authors introduced a numerical nomenclature (CE-1 to CE-8, see Fig. 1) for a series of centuryscale cold periods during the Holocene. Some of the most severe oscillations seem synchronous with cool climatic periods recorded in the Northern Atlantic marine sediments and in Greenland ice cores.

\section{Temperature, Precipitation or both?}

Timberline fluctuations may be caused by changes in temperature, precipitation or both. Comparison with other proxies helps to disentangle temperature and precipitation effects. Timberline forests show oscillations similar to those of alpine glaciers during most of the Holocene. The most pronounced glacier minima were synchronous with uppermost timberline positions (Fig. 1) between 9,000 and 8,200 cal. yr $\mathrm{BP}, 7,000$ and 6,400 cal. $\mathrm{yr} \mathrm{BP}$, as well as 5,000 and 4,000 cal. yr BP (Hormes et al., 2001). Maximum glacier advances (Maisch et al., 1999) occurred coincident with timberline depressions (CE-2 to CE-8). A further indication that high Holocene timberline positions reflect warm and dry conditions is provided by Holocene lake level changes across the Alps (e.g. Magny and Richoz, 1998; Magny and Schoellammer, 1999).
For example, in the Swiss Jura and on the Swiss plateau (e.g. Le Locle and Seedorf, Fig. 1), lake levels were at a minimum during the Holocene warm phases $(9,000-8,200$; 7,000 - 6,400; 5,000 - 4,000 cal. yr BP.) and at a maximum during most cold phases (Fig. 1). Hence middle- and late-Holocene climatic reversals may have been comparable to the Little Ice Age climatic cooling around AD 1850, when cool summers where accompanied by increased precipitation. However, overall early Holocene climatic conditions in the Alps were more continental than today, with warm and dry summers and cold winters. The transition to today's climatic regimes was not synchronous. For example, in the southern Alps (between Aosta and Garda in Italy and southern Switzerland), the continental climatic regime came to an abrupt end at about 9,100 cal. yr $\mathrm{BP}$, allowing the establishment of the so called Insubrian vegetation (Tinner et al., 1999). In the northern Alps and Central Europe, a similar sudden transition occurred at 8,200 cal. yr BP (Tinner and Lotter, 2001). This latter transition was probably caused by increased inflow of humid air masses from the west and north-west, leading to lower summer and higher winter temperatures and a general increase in the amount of precipitation. Because of the special orographic situation, the continental climate mode has persisted in some valleys of the central Alps until today.

\section{Towards a paleoecological approach}

The temporal resolution of the above-mentioned studies (50-300 years) is sufficient to indicate major Holocene climatic oscillations and trends. However, it is insufficient to address how, and how fast, organisms react to environmental changes. In and around the Alps, two recent studies (Ammann et al., 2000; Tinner and Lotter, 2001) follow a new approach to address this question. Based on highly reliable calendar chronologies (varves, calendar years), they compared independent climatic (oxygen isotopes) 
and biotic proxies. These studies suggest that different organisms (e.g. plants, cladocera, chironomidae) responded very fast to climate change during the Late Glacial and the Holocene (i.e. within 0-20 years). In the case of the Holocene study, vegetational responses to climate change were highly complex and related to physiological characteristics and life histories of the species involved. The resulting interspecific competition patterns were so complex that the response signal was not recognized as climatically driven in numerous previous studies, although it occurred on a subcontinental scale.
We conclude that because of the complex orographic situation and the resulting highly differentiated biome belts in the Alps, high temporal and spatial precision and resolution are required to provide a clear understanding of past climate changes and ecosystem responses. Such high resolution studies are also essential to overcome seeming differences between modern ecological and paleoecological paradigms of ecosystem functioning.

\section{ACKNOWLedgements}

Improvements of the manuscript by Herbert E. Wright Jr. are gratefully acknowledged.

\section{REFERENCES}

Haas, J.N., Richoz, I., Tinner, W. and Wick, L. 1998: Synchronous Holocene climatic oscillations recorded on the Swiss Plateau and at timberline in the Alps. The Holocene, 8: 301-309.

Magny, M. and Richoz, I., 1998: Holocene lake-level fluctuations in Lake Seedorf, southern Swiss Plateau. Eclogae geol. Helv., 91: 345-357.

Maisch, M., Wipf, A., Denneler, B., Battaglia, J. and Benz, C., 1999: Die Gletscher der Schweizer Alpen. Gletscherhochstand 1850, Aktuelle Vergletscherung, Gletscherschwund-Szenarien. vdf, Zürich, 373 pp.

Tinner, W., Ammann, B. and Germann, P., 1996: Treeline fluctuations recorded for 12,500 years by soil profiles, pollen, and plant macrofossils in the central Swiss Alps. Arctic and Alpine Research, 28(2): 131-147.

For full references please consult:

www.pages-igbp.org/products/newsletter/ref20013.html

\section{Paleoenvironmental Reconstructions for Mountains in the Eurasian Mid-Continent}

\footnotetext{
*Tatiana Blyakharchuk1, Ivanka Stefanova2, Herbert E. Wright3 and Brigitta Ammann4

1 Scientific Research Institute of Biology and Biophysics, Tomsk State University, 634050Tomsk, Russia, ta@pochta.tomsk.ru 2 Institute of Botany, Academy of Sciences, Sofia, Bulgaria, Current Address: Park Street, New Haven, USA, vanja_stefanova@yahoo.com 3 Limnological Research Center, University of Minnesota, Minneapolis MN 55455 USA, hew@maroon.tc.umn.edu

4 Institute of Plant Sciences, University of Bern, Switzerland, brigitta.ammann@ips.unibe.ch
}

Paleoenvironmental reconstructions for the Pirin Mountains (southwestern Bulgaria) and the Altai Mountains (southern Siberia, Fig.1) provide insight into the relationships between long-term vegetation dynamics and orbital forcing at two high-elevation sites in the Eurasian mid-continent. The topography of mountain regions constrains vegetation into distinct altitudinal bands, and these bands are sensitive to changes in both temperature and effective moisture through time. The sequence of late-glacial and early-Holocene vegetational change and the vertical displacement of vegetational bands are reconstructed for these mountains by pollen analyses at multiple sites along altitudinal gradients. However, the complexities associated with the dry early-Holocene conditions at these mid-continent sites require additional studies in order to disentangle the various responses of taxa to long-term regional climatic changes.

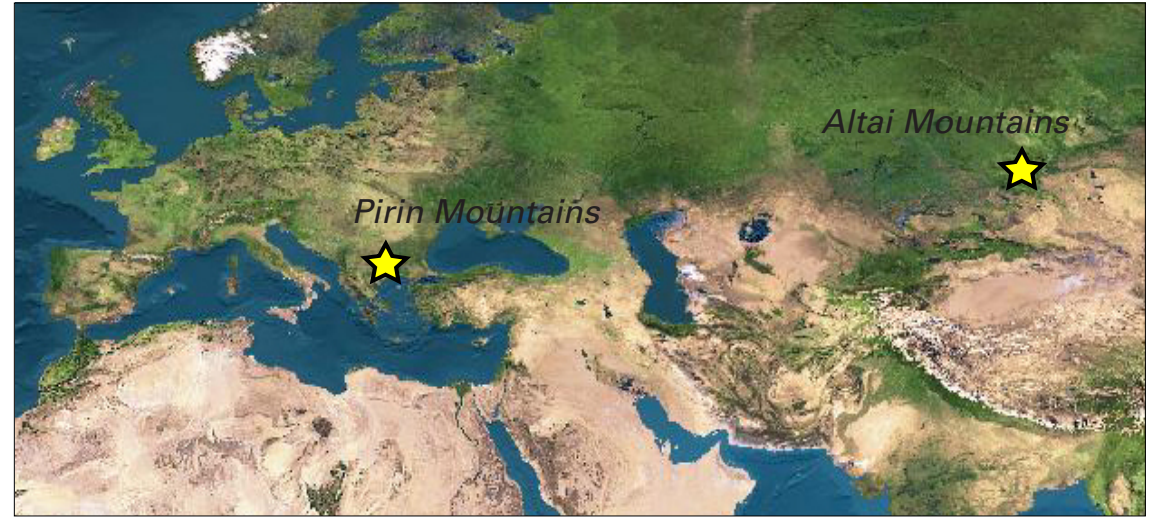

Fig. 1: Location of the two case-study areas in the Eurasian mid-continent

\section{Long-term vegetation dynamics in the Pirin Mountains,} Bulgaria

The Pirin Mountains are situated in the eastern part of the Balkan Peninsula. The climate is more continental and significantly drier than in the Alps. Temperate deciduous trees occur at low elevation, followed by beech and then various conifers extending up to the tree line at about 2,200 m. Of particular biogeographic interest in the Pirin Mountains is the common occurrence of the Balkan endemic Pinus peuce and (on calcareous soils) the Balkan sub-endemic Pinus heldreichii.

Pollen analysis of lake sediments, recovered from several sites near tree line, reveals an unusual sequence of changes in forest composition. After a late-glacial sequence dating back to $13,000{ }^{14} \mathrm{C}-\mathrm{yr}$ BP at lake Kremensko, the early-Holocene tree line was formed by birch which did not reach as high as the modern tree line (Fig. 2). At Dalgoto Lake close to modern tree line, the early-Holocene pollen assemblage of oak, elm, linden and

\footnotetext{
* The investigations in the Pirin Mountains were undertaken by Ivanka Stefanova, and those in the Altai Mountains by Tatiana Bliakhartchouk. H.E. Wright and Brigitta Ammann participated in the field work and aided in the interpretation of the pollen stratigraphy in both areas.
} 


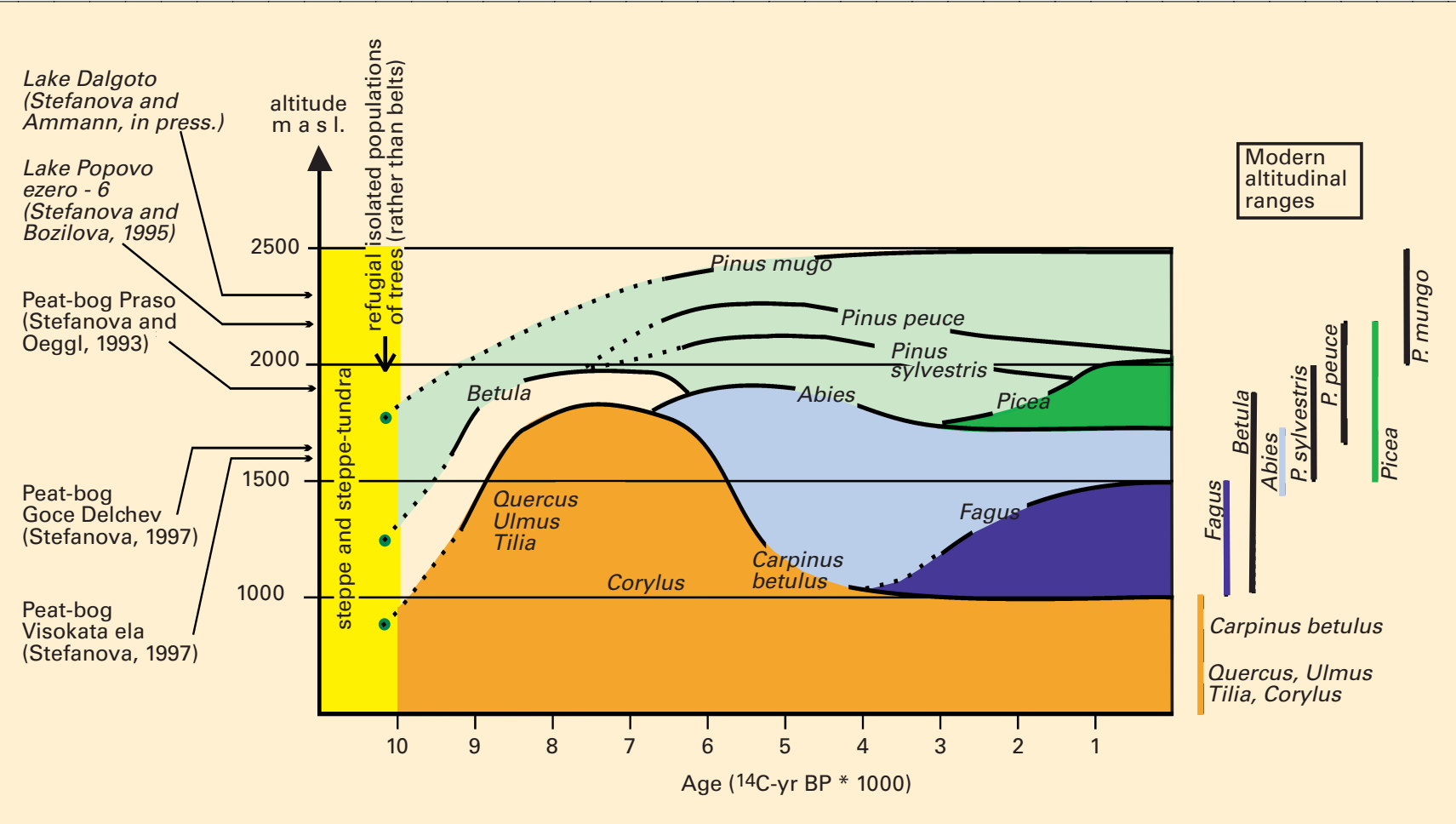

Fig. 2: Altitude-time diagram for the Holocene forest belts in the Pirin Mountains, showing for the early Holocene the high altitudinal range of deciduous forest and the low treeline, followed in the mid-Holocene by the immigration and expansion of conifers, resulting in a depression of the deciduous forest and the increased elevation of the treeline. The belts are simplified, and only the upper limits of tree species or genera are shown. Within the belts taxa may mix, e.g. spruce and fir in the belt marked in blue. At the sites Lake Popovo, Praso and Goce Delchev the analysis of plant macrofossils helped to distinguish between presence and absence of tree genera. (Adapted from Stefanova and Ammann, in press.).

hazel is attributed entirely to transport of pollen from lower-elevation forests to above the forest limit, where the treeless landscape had low pollen production (Stefanova and Ammann, in press). However, oak macrofossils at sites as much as $800 \mathrm{~m}$ above the present range of oak clearly demonstrates that the temperate forest reached higher elevations during the early Holocene, perhaps in response to the warmer summer temperatures associated with higher insolation (Fig. 2).

After about 6,500 ${ }^{14} \mathrm{C}-\mathrm{yr} \mathrm{BP}$, the immigration and expansion of conifers (Pinus sylvestris, $P$. peuce, $P$. mugo, and Abies alba) to higher elevations depressed the temperate forest to elevations below 1,000 m. Beech and spruce subsequently expanded after ca. $3,000{ }^{14} \mathrm{C}$-yr BP. This late expansion of conifers in the Pirin Mountains is unexpected in view of the occurrence of pine macrofossils of glacial age in the nearby lowlands of Hungary (Willis et al., 2000). Clearly, long-distance migration cannot be invoked to explain the delayed immigration of conifers to the Pirin Mountains.
Rather, it is more likely that climatic conditions were unfavorable for high-elevation conifers until the late Holocene.

Although broad-leaved trees such as oak, elm, and linden reached elevations higher than present during the early Holocene, this apparently occurred in conjunction with a treeless zone that extended to elevations lower than today. The late expansion of the conifers, which are better adapted to high elevations than broad-leaved trees, shifted the deciduous forest down and the treeless zone up to their present ranges.

Dry early-Holocene climatic conditions in Eastern Europe may have been the cause for the unusual forest history in the Pirin Mountains. Along the Black Sea coast, eastern Bulgaria was dry enough for steppe to persist until the spread of deciduous forest about $8,000{ }^{14} \mathrm{C}$-yr BP. (Bozilova et al., 1996). Farther east in the Zagros Mountains of Iran, which are currently too dry for pine, the slow early-Holocene spread of oak and pistachio into grass steppe also implies dry climatic conditions.
This scenario is further supported by evidence from the Altai Mountains (below) in southern Siberia where the persistence of steppe vegetation until at least $9,000{ }^{14} \mathrm{C}$ yr BP and late afforestation by pine again provides an indication of dry early-Holocene conditions in the Eurasian mid-continent.

\section{Long-term vegetation dynamics in the Altai Mountains, Siberia}

The Altai Mountains are located in the centre of Eurasia where Russia, Khazakhstan, Mongolia and China meet. Sediment cores from an altitudinal transect of lakes on a high plateau south of Ulagan provide the opportunity to trace the vegetational history from late-glacial time to the present by pollen analysis of organic sediment. Earlier findings of abundant spruce and pine macrofossils at a site $200 \mathrm{~km}$ to the north and 1,000 $\mathrm{m}$ lower in elevation are dated to ca. $13,750{ }^{14} \mathrm{C}-\mathrm{yr}$ BP and indicate an area where a late-glacial refuge for these conifers may have existed.

Three lakes, at elevations ranging from 1,950 $\mathrm{m}$ in the upper for- 
est zone to 2,150 $\mathrm{m}$ at treeline, have very similar pollen records, well dated by radiocarbon analysis. Following a brief conifer zone in silt which may represent long-distance pollen transport to a barren landscape, the main sequence starts in organic sediment more than 13,000 ${ }^{14} \mathrm{C}$-yr ago with a steppe flora dominated by Artemisia, grasses, sedges, and chenopods, with spruce as division of the steppe phase into late-glacial interstadial and stadial intervals is not apparent. The persistence of steppe vegetation during the late-glacial (Tarasov, 2000; Chernova et al., 1991) may reflect the dominance of cold and dry northeasterly air flow from the Siberian anticyclone (Tarasov, 1997) which a minor component (Fig. 3). Sub-

was strengthened by the supply of circum-polar arctic air north of the ice sheets on both continents. The dominance of steppe vegetation persisted until at least 9,000 ${ }^{14} \mathrm{C}$-yr BP, when increases in pollen of Siberian pine and Scots pine indicate broad afforestation.

Thus, not only was the late-glacial vegetational sequence in these interior mountains different from the observed sequence at sites closer to the Atlantic source of climatic change, but the ubiquitous expansion of forest seen in the Alps and other mountains and lowlands of Europe at the end of the late-glacial $\left(10,000{ }^{14} \mathrm{C}-\mathrm{yr} \mathrm{BP}\right)$ did not occur in the Altai until 1,000 years later (Fig. 3). The continuation of steppe conditions well into the Ho-

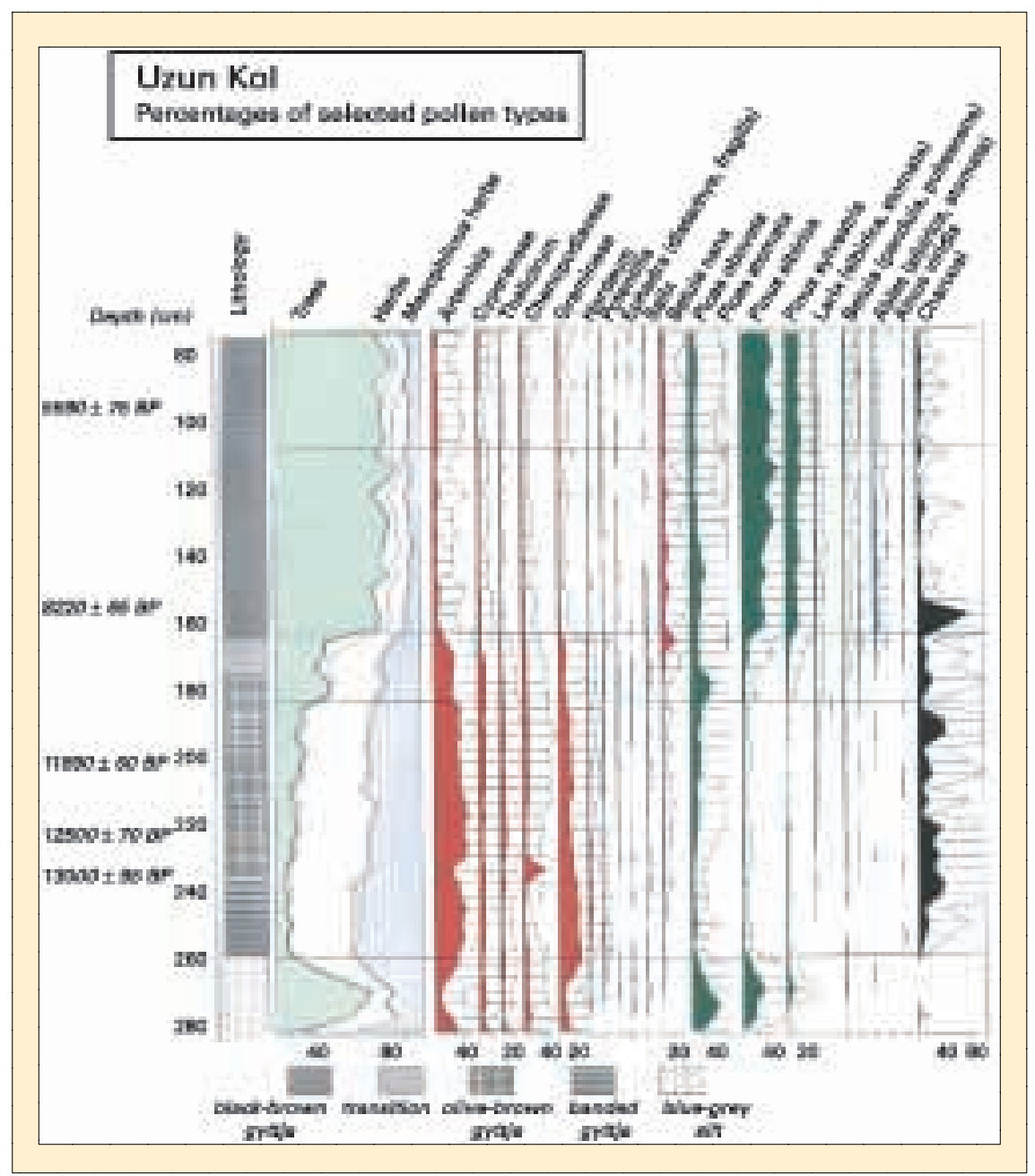

Fig. 3: Percentages of selected pollen taxa at Uzun Kol, Altai, Siberia, at 1,985 m asl. The basal zone in the silt is poor in pollen and is dominated by tree pollen (3 origins are possible: long-distance transported, reworked, or original from refugial habitats for trees). The period of the banded gyttja and the olive-brown gyttja (Late-Glacial and Early Holocene up to about 9,500 radiocarbon yrs BP) is dominated by steppe vegetation. After a transition zone of about 1,000 years the local conifers expanded: Pinus sibirica and Larix sibirica near the lake Uzun, Scots Pine, spruce and even the demanding fir at lower elevations in the Ulagan Valley locene can be attributed to warm, dry summers related to the insolation maximum. Unfortunately, cold late-glacial steppe vegetation cannot easily be distinguished from warm Holocene steppe by palynological analysis.

These findings provide support for paleoclimatic model simulations that reconstruct cold and dry conditions maintained by northeasterly winds at $12,000{ }^{14} \mathrm{C}$-yr BP and summer temperatures $2-4^{\circ} \mathrm{C}$ higher than present at 9,000 ${ }^{14} \mathrm{C}$-yr BP in southern Siberia (COHMAP members 1988).

This temporal sequence of steppe, persisting in the Altai Mountains from the late-glacial into the early Holocene, resembles the biogeographic sequence across the region today. Forests in the more humid west grade into steppe vegetation in the east, where trees are restricted to patches on northfacing slopes. The pollen stratigraphy of sediments recovered from mountain lakes in the eastern dry region, now the focus of a continuing study, will address the question whether or not steppe vegetation was present throughout the Holocene, despite long-term changes in summer insolation.

\section{REFERENCES}

Bozilova, E., Filipova, M., Filipovich, L. and Tonkov, S., 1996, Bulgaria. In Berglund, B.E., Birks, H.J.B., Ralska-Jasiewiczowa, M. and Wright, H.E. editors, Paleoecological Events During the Last 15000 Years: Regional Syntheses of Paleoecological Studies of Lakes and Mires in Europe, Chichester: John Wiley and SonsLtd, 701-728.

Chernova, G.M., Mikhailov, N.N., Denisenko, V.P., Kosyreva, M.G. 1991, Some questions of paleogeography of Holocene of southeastern Altai (in Russian). Izvestiya vsesoyuznogo geograficheskogo obshestva, Vyp 2., 140-146.

Tarasov, P.E., Jolly D., Kaplan J.O. 1997, A continuous Late Glacial and Holocene record of vegetation changes in Kazakhstan. Palaeugeography, Paleoclimatology, Paleoecology 136: 281-292.

Stefanova, I. 1997, New data on the Late Holocene vegetative succession in the Northern Pirin Mts.: pollen and macrofossil analysis of depositions from peat bogs Goce Delchev and Visokata Ela.Phytologia Balcanica, 3/2-3.

Stefanova, I. and Ammann, B., in press, Late Glacial and Holocene vegetation belts in the Pirin Mountains (southwestern Bulgaria. The Holocene

For full references please consult:

www.pages-igbp.org/products/newsletter/ref20013.html 


\title{
Changes in Atmospheric Circulation over the South-Eastern Tibetan Plateau over the last Two Centuries from a Himalayan Ice Core
}

\author{
Cameron P. Wake 1, Paul A. Mayewski², Dahe Qin 3, Qinzhao Yang1, Sichang Kang3, Sallie Whitlow1, and L. David Meeker 1 \\ 1 Climate Change Research Center, University of New Hampshire, Durham, USA, cpw@gust.sr.unh.edu \\ siw@unh.edu, david.meeker@unh.edu \\ 2 Institute of Quaternary and Climate Studies, University of Maine, Orono, ME, paul.mayewski@maine.edu \\ 3 Lanzhou Institute of Glaciology and Geocryology, Academia Sinica, Lanzhou, China, kangsc@|zu.edu.cn
}

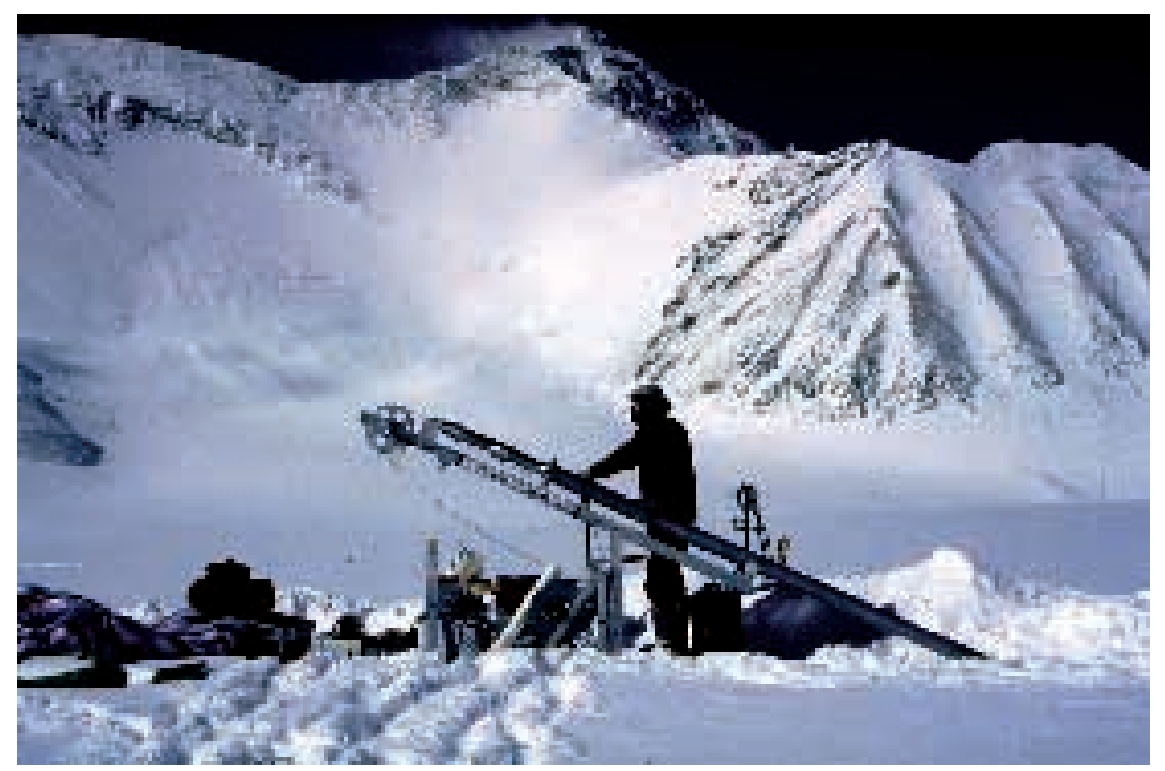

Fig. 1: The Eclipse ice core drill at $6500 \mathrm{~m}$ on the Far East Rongbuk Glacier with Mt. Everest in the background. Photo. C. Wake.

\section{Introduction}

Understanding climate change in central Asia is especially important given the role of the Tibetan Plateau in regional and global atmospheric circulation. Climate in the region is dominated by the Asian monsoon which provides summertime life sustaining rains for hundreds of millions of people. While long-term variability (thousands of years) of the Asian monsoon has been linked to changes in northern hemisphere insolation, shorter-term variability (years to decades) has been explained by changes within the climate system, such as variations in Eurasian snow cover, the El Niño-Southern Oscillation, and tropical sea-surface temperatures. More recently, model results have suggested the importance of anthropogenic forcing (e.g. greenhouse gas, landcover change) for the Asian monsoon.

Ice cores recovered from high elevation glaciers in the Himalaya contain high resolution records that can be used to document annual to century scale changes in the Asian monsoon. Here we docu- riod from 1815 to 1997 . We estimate that the dating error from 1997 to 1954 is \pm 2 years, and below 1954 may double to \pm 4 years due to the lack of reference horizons in this section of the record.

\section{Results and Discussion; Major Ion Chemistry}

Seven of the eight major ions $\left(\mathrm{Na}^{+}\right.$, $\mathrm{K}^{+}, \mathrm{Mg}^{2+}, \mathrm{Ca}^{2+}, \mathrm{Cl}^{-}, \mathrm{NO}_{3}^{-}, \mathrm{SO}_{4}{ }^{2-}$ ) show similar temporal variability (correlation coefficients among all seven ions is greater than 0.75 ) indicating that most of the major ion chemistry either has a common source (i.e., the arid and semiarid dust producing regions on the northwestern margin of the Tibetan Plateau) or has separate sources that lie at a sufficient distance upwind that the major ions from different sources have time to become well mixed by the time they are deposited ensemble on the FER glacier. Previous work has shown that the spatial variation of snow chemistry in central Asia is controlled by the influx of dust from the arid and semi-arid regions in the northern and western Tibetan Plateau. A comparison of major ion chemistry from the FER glacier with data from Nangpai Gosum glacier over the last 20 years illustrates the importance of the Himalaya as a divide between dust-rich air masses to the north and relatively dust-free air masses to the south (Table 1). In addition, $\mathrm{Na}^{+}$and $\mathrm{Cl}^{-}$concentrations in snow samples collected on the southern flank of Mt. Everest are approximately one-tenth and one-half those at FER glacier (Table 1) indicating that $\mathrm{Na}^{+}$and $\mathrm{Cl}^{-}$ do not originate from modern marine sources to the south, but from evaporite deposits in the arid regions of the northern and western Tibetan Plateau that are likely transported with calcium-rich desert dust to the FER glacier. 


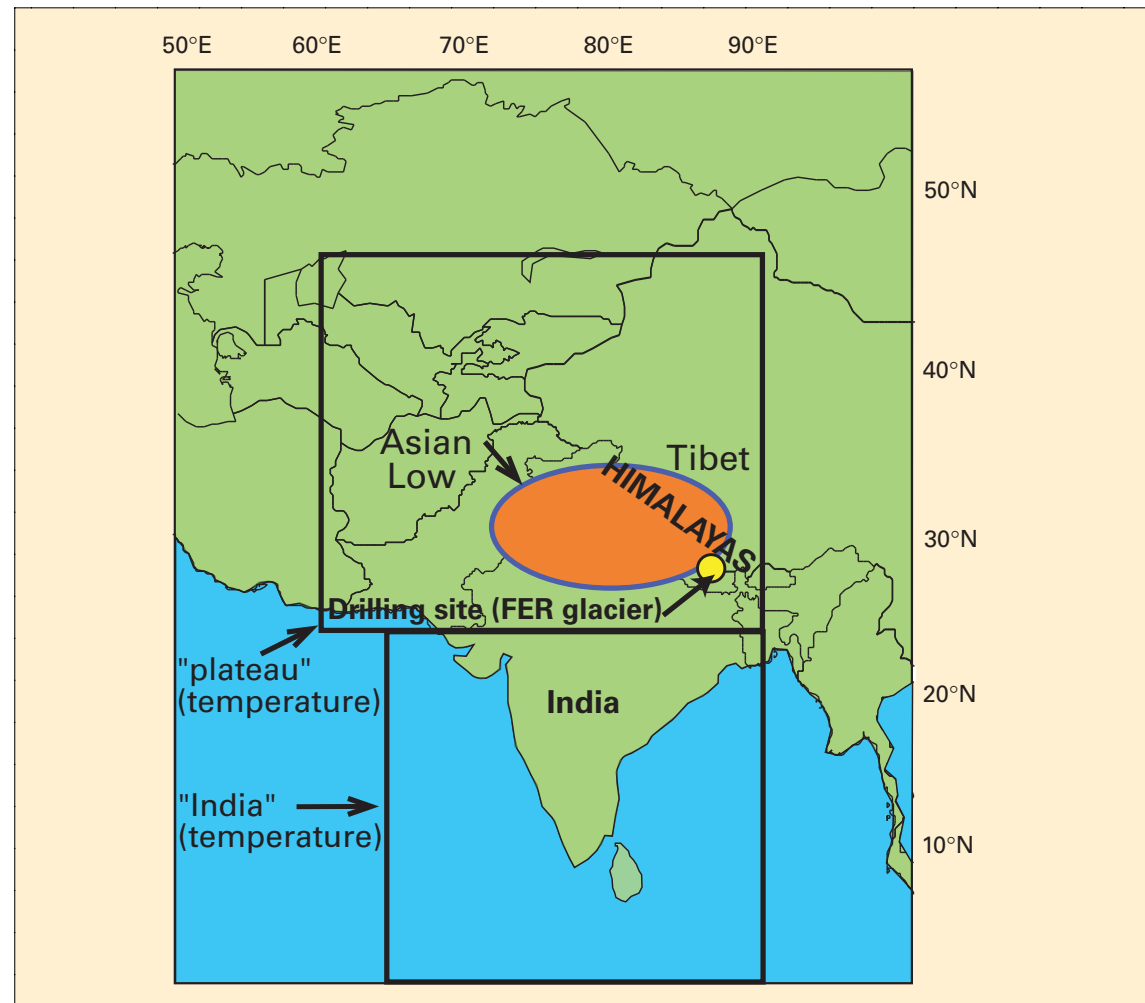

Fig. 2: Location map for the Far East Rongbuk (FER) glacier and areas for instrumental data used for comparison with the FER ice core record.

\section{Comparison with Climate Records}

To investigate the relationship between the glaciochemical ice core record and climate, we have compared the FER calcium record with seasonal or annual averages of regional temperature (Hansen et al., 1996), solar irradiance (Lean et al., 1995), the southern oscillation index (SOI), regional precipitation (Parthasarathy et al., 1992), and sea level pressure (Trenberth and Paolino, 1980) over the longest period of overlap of these records (i.e., 1899-1992).

While the traditional measure of the strength of the Asian summer monsoon is precipitation over a particular region (e.g., the All-India precipitation index), we have also developed a measure of regional summertime atmospheric circulation that estimates the strength of the summertime Asian Low using $5^{\circ}$ $\times 5^{\circ}$ global sea-level pressure (SLP) data following methods developed by Trenberth and Paolino (1980). For our Asian Low index, we have averaged the monthly SLP for June, July, and August within the region of $15^{\circ}-60^{\circ} \mathrm{N}$ and $40^{\circ}-136^{\circ} \mathrm{E}$. The center of activity of the summertime Asian low from June through Au- gust commonly lies north of the Indian subcontinent within the region chosen for the Asian Low index (Fig. 2).

A direct comparison of the Asian Low index with All-India precipitation shows little correlation among the two variables. While precipitation is arguably the most societally important climatic variable in the region, it remains one of the most difficult parameters to measure and interpret over a broad region due to the difficulty of differentiating the influence of geographical factors on precipitation versus changes in circulation, and the spatial limitation of the precipitation data base which covers only a portion of the land area under the influence of the monsoon and none of the adjacent ocean (Webster and Yang, 1992). Furthermore, a comparison between precipitation fluctuations over the Himalaya and India does not show good agreement.

Comparison between the annualized FER calcium record and the climate variables mentioned above was accomplished using multivariate EOF analysis rather than repeated simple linear regressions because of its ability to assess joint behavior of several variates (i.e., major ions). The first EOF explains almost half of the variance in the SOI and approximately two-thirds of the variance in the regional temperature records (Table 2). The inverse relationship between the SOI and temperature in continental regions identified in EOF1 has previously been identified in several studies. EOF1 also reveals a positive relationship between solar variability and temperature in central Asia and India, reflecting the link between increases in solar irradiance and warmer climate. EOF2 is loaded on the Asian Low, FER calcium, and All-India precipitation. High calcium concentrations in the core correspond to a deeper summertime Asian low (i.e., lower sea-level pressure) (Fig. 3) and an increase in summertime precipitation. Webster and Yang (1992) show that strong monsoons (i.e., stronger Asian Low and more rain) are associated with a substantial increase in $200 \mathrm{mb}$ zonal winds from $30^{\circ}-45^{\circ} \mathrm{N}$ in central Asia in DJF and MAM preceding the summer of the strong monsoon, while weak monsoons are associated with a decrease in

Table 1: Median major ion concentrations ( $\mu$ eq $\mathrm{kg}^{-1}$ ) for Far East Rongbuk (FER, $n=80$ ) and Nangpai Gosum (n=493) ice core samples over the past 20 years.

\begin{tabular}{|lll|}
\hline Species & FER & $\begin{array}{l}\text { Nangpai } \\
\text { Gosum }\end{array}$ \\
\hline $\mathrm{Ca}^{2+}$ & 8.61 & 0.21 \\
$\mathrm{NH}_{4}{ }^{+}$ & 2.07 & 0.97 \\
$\mathrm{Mg}^{2+}$ & 0.77 & 0.05 \\
$\mathrm{Na}^{+}$ & 0.62 & 0.05 \\
$\mathrm{~K}^{+}$ & 0.14 & 0.03 \\
$\mathrm{NO}_{3}{ }^{-}$ & 1.30 & 0.24 \\
$\mathrm{SO}_{4}{ }^{2-}$ & 0.81 & 0.05 \\
$\mathrm{Cl}^{-}$ & 0.52 & 0.26 \\
\hline
\end{tabular}

these zonal winds in the two seasons preceding the weak monsoon. An increase in zonal winds over the desert regions in western Asia during a strong monsoon transports more dust eastward and result in higher ion concentrations in snow on the FER glacier, and vice versa during weak monsoons. The inverse relationship between the FER calcium record and the Asian Low is somewhat counter-intuitive as one might expect an increase in precipitation to decrease dust levels. However, this would only occur if the 
source of the dust was from the Indian subcontinent. Our spatial analysis of snow chemistry in central Asia (Table 1) indicates that the dust is actually derived from the arid regions of the western and northern margins of the Tibetan Plateau.

The direct relationship between FER calcium and the Asian Low is not strong $(r=-0.31)$ but significant on the $99 \%$ level. However, the relationship becomes clearer once the effects of temperature, solar radiation, and ENSO on the strength of the Asian Low are accounted for, using multivariate EOF analysis. While not perfect, the FER ice core calcium record does provide a proxy record of summertime Asian monsoon circulation via the association between the summer monsoon and $200 \mathrm{mb}$ zonal flow over central Asia, with higher FER calcium concentrations relating to a stronger monsoon. We therefore use the longer-term FER calcium record to interpret changes in atmospheric circulation in this region over the last 200 years. The interannual variability of the Asian Low, as evidenced in the sea level pressure records, has in-

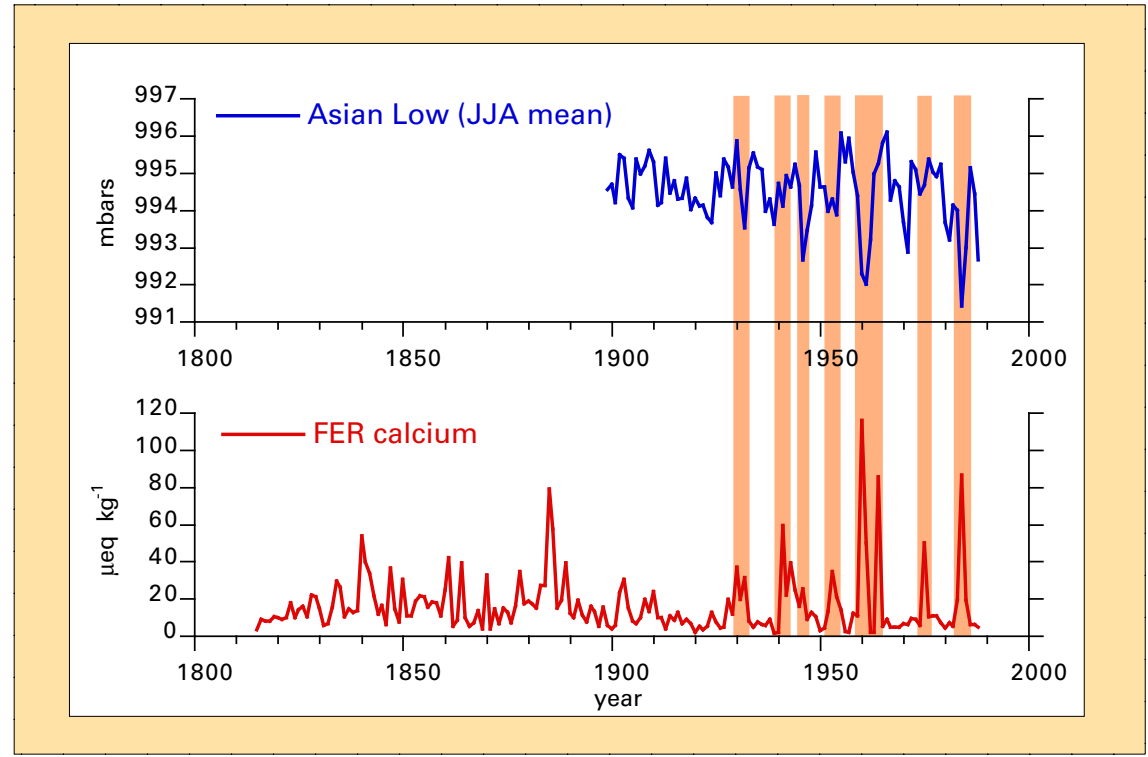

Fig. 3: Comparison of the Far East Rongbuk (FER) ice core calcium record and the Asian low index.

toward deeper Asian Lows over the past 50 years suggested by our 200 year FER calcium record may represent an enhanced monsoon, forced by a recent increase in the atmospheric concentration of greenhouse gases. This would also imply an increase in the strength of westerly circulation (i.e., $200 \mathrm{mb}$ zonal winds from $30^{\circ}-45^{\circ} \mathrm{N}$ in central Asia) in the 6 months period pre-

Table 2: EOF associations between climatic variables and the Far East Rongbuk (FER) glacier calcium record for the period 1899-1991.

\begin{tabular}{|lcc|}
\hline \multicolumn{1}{|c}{ Parameter } & $\begin{array}{c}\text { EOF1 - clim } \\
(33.0 \%)\end{array}$ & $\begin{array}{c}\text { EOF2 - clim } \\
(21.9 \%)\end{array}$ \\
\hline Temperature "plateau" & 62 & 0 \\
Temperature "India" & 75 & -12 \\
Solar activity & 39 & 11 \\
Southern Oscillation Index & -43 & 12 \\
All-India summer precipitation & 0 & 39 \\
Asian Low & -16 & -37 \\
Far East Rongbuk Glacier Calcium & 2 & -39 \\
\hline
\end{tabular}

creased since 1940 with especially deep summertime lows occurring in 1871, 1946, 1960-61 and 1983 (Figure 3). The longer-term FER calcium record suggests that while the calcium spikes are not unique to the past 50 years, recent values are higher than in the past. This trend is not apparent in the precipitation record (Parthasarathy et al., 1987). Circulation models suggest an increase in the strength of summer monsoon circulation with increased global temperatures resulting from increased concentration of greenhouse gases. The trend ceding the monsoon and increase in dust transport from the Tibetan plateau to the FER glacier.

\section{Conclusions}

The major ion chemistry of snow at the FER glacier is dominated by the influx of mineral aerosol derived from the western and northern regions of the Tibetan Plateau, supporting previous research. Through comparison of the FER calcium record with a variety of climate indices, we have documented a relationship between dust deposition it the Himalaya and the strength of the Asian Low. This relationship can be explained by a link with the upper level westerlies over the Tibetan plateau which are stronger in the winter/spring preceding a strong monsoon (Webster and Yang, 1992). This strengthened circulation would be responsible for an increase in dust deposition on the northern slope of the Himalaya. Our records suggest that there has been an increase over the past fifty years in the strength of the Asian Low. This is consistent with model results that suggest an increase in the strength of the Asian monsoon in a world warmed by greenhouse gases. While tentative, our results suggest ice core records provide a valuable contribution to documenting and understanding decadal-tocentury scale variability of the Asian monsoon.

\section{REFERENCES}

Hansen, J., R. Reudy, M. Sato and R. Reynolds, 1996, Global surface air temperature in 1995: Return to pre Pinatubo levels, Geophys. Res. Lett. 23, 1665-1668,

Lean, J., J. Beer and R. Bradley, 1995, Reconstruction of solar irradiance since 1610: Implications for climate change, Geophys. Res. Lett., 22, 3195-3198,

Parthasarathy, B., Rupa Kumar, K., and Kothawale, D.R. 1982, Indian summer monsoon rainfall indices: 1871-1990, Meteorological Magazine 121, 174-186,

Trenberth, K.E. and D.A. Paolina, Jr., 1980, The Northern Hemisphere sea-level pressure data set: trends, errors and discontinuities, Mon. Weather Rev., 108, 855-872.

Webster, P.J. and S. Yang, 1992, Monsoon and ENSO: Selectively interactive systems, 0 . J. R. Meteorol. Soc., 118, 877-926 


\section{The Assessment of Present, Past and Future Climate Variability in the Americas from Treeline Environments}

Brian H. Luckman ${ }^{1}$ and José A. Boninsegna 2

1 Department of Geography, University of Western Ontario, London, Ontario, Canada, luckman@uwo.ca

2 Laboratorio de Dendrocronologia, IANIGLA-CONICET, Mendoza, Argentina, pbonin@lab.cricyt.edu.ar

In this note we introduce one of 14 Collaborative Research Networks (CRN) funded by the Inter-American Institute for Global Change Research. It was established in 1999 and involves 15 principal investigators from 13 institutions in Canada, USA, Mexico, Bolivia, Chile and Argentina. The primary goals of the project are (i) to develop a network of tree-ring chronologies from climatically-sensitive treeline sites in the western American Cordillera and (ii) to use these data to reconstruct and compare regional interannual to decadal climate variability along the PEP-1 transect from Alaska to Tierra del Fuego. The project also seeks to enhance the development and utilization of dendrochronology for tropical mountain tree species and expand collaboration, training and the application of paleoenvironmental science within Latin America to address the issues of climate variability and change.

\section{The existing Chronology}

The existing tree ring chronology coverage of the American Cordillera is patchy (see Fig. 1) and the initial sampling has targeted significant geographical gaps and key areas. We anticipate that the development of this more comprehensive geographical coverage will allow the reconstruction of spatial and temporal patterns of temperature and precipitation along this transect over the last several hundred years. Documentation of these changing spatial patterns is key to understanding the controls of climate variability. Several new chronology networks have been developed since the inception of the project. In the Southern Canadian Cordillera three new single species chronology networks have been developed for temperature reconstructions at upper treeline sites. A complementary network of 53 lower treeline moisture-sensitive sites has also been assembled and is being used to derive maps of annual precipitation anomalies and to assess drought frequency and intensity for the region over the last 300 years. Extensive sampling is also planned for temperature reconstructions from treeline sites across northern British Columbia and the Yukon in the next few years. In Mexico the new sampling programs have primarily targeted Douglas Fir and Montezuma Bald cypress stands across central and Northern Mexico to develop precipitation and drought reconstructions that have obvious applications to agriculture and forestry in addition to their paleoclimate significance. In South America, Nothofagus pumilo (lenga) dominates treeline sites in the southern Andes of Chile and Argentina. A network of over 90 lenga sites between $35^{\circ}$ and $55^{\circ} \mathrm{S}$ has been used to develop reconstructions of annual temperatures for northwestern and southern Patagonia between AD 1630 and 1987. Both reconstructions reveal the unusual nature of regional climate conditions during the 20th century when compared with the past 400 years. New chronologies have also been developed for Austrocedrus chil-

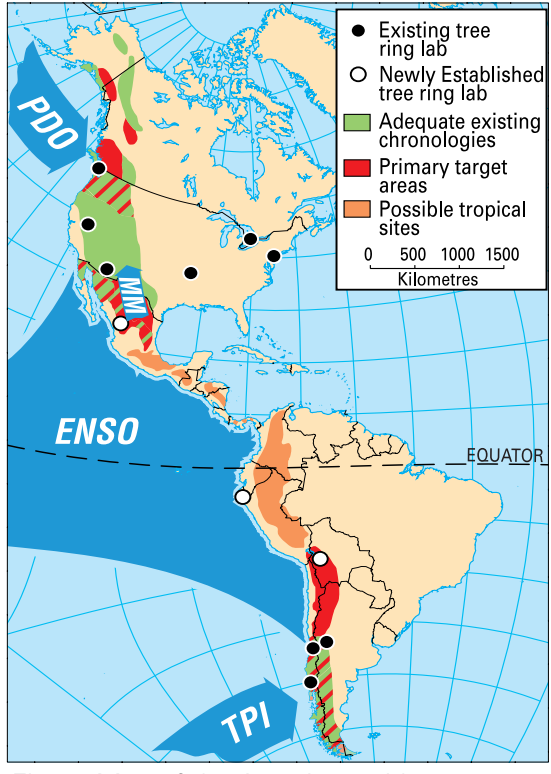

Fig. 1: Map of the Americas with prospective sampling areas and location of participating tree-ring laboratories.

(MM= Mexican Monsoon; TPl= Trans-Polar Index; $P D O=$ Pacific Decadal Oscillation)

ensis in both Chile and Argentina with a maximum length of over 1800 years that will yield long precipitation and ENSO reconstructions. Tree growth in many of these tree-ring series is strongly correlated with sea surface temperatures (SST) in adjacent areas of the Pacific and Atlantic Oceans (Fig. 2). Reconstructing the spatial and temporal variability of Pacific SSTs will

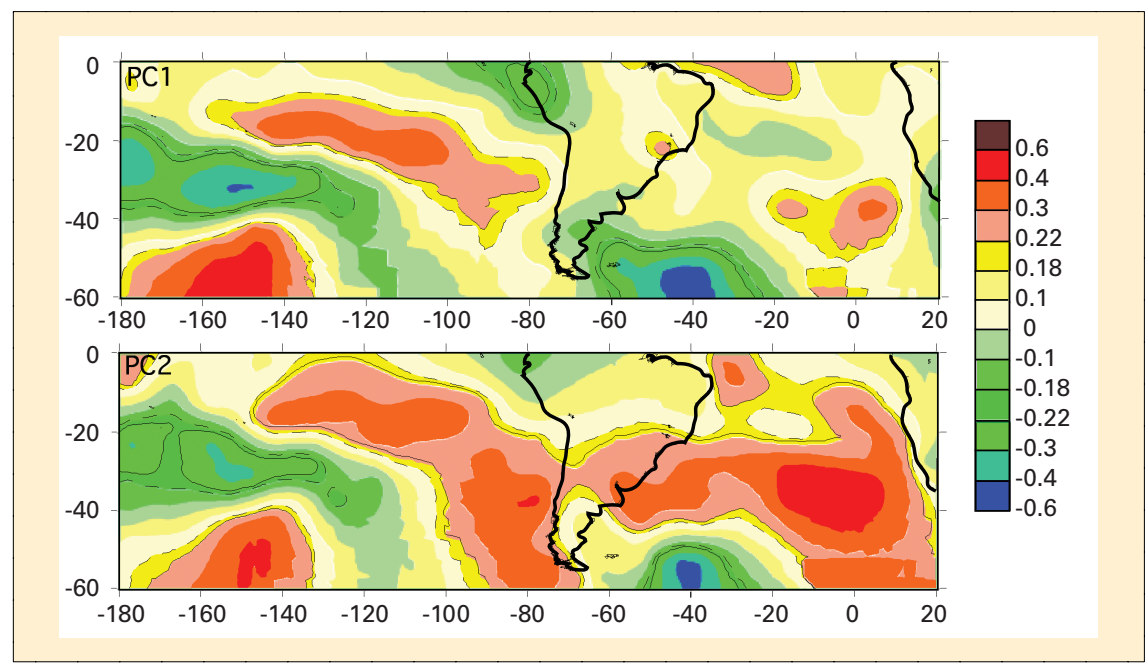

Fig. 2: Correlation fields between reconstructed temperatures in NW (above) and Southern Patagonia (below), based on lenga tree-ring width chronologies and SSTs across the South Pacific and South Atlantic. 


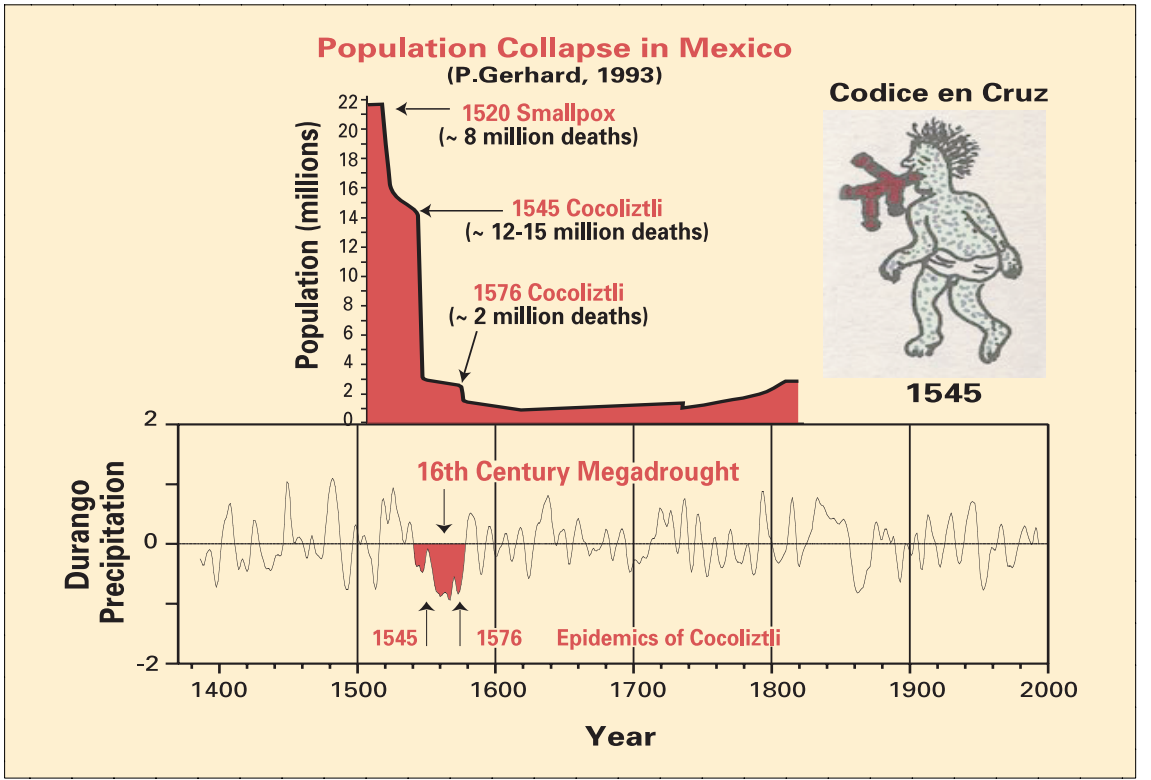

Fig. 3: Relationships between drought and disease in $16^{\text {th }}$ century Mexico (after Acuna-Soto et al., in press). The drawing is reproduced from contemporaneous sources.

enhance our understanding of the global climate system (e.g. in studies of EI Niño, PDO and their interrelationships). In conjunction with ongoing dendroclimate work, several investigators are also using dendrochronology to date glacier fluctuations of the last millennium in Canada, Chile and Argentina.

\section{The Mexican "Megadeath"}

In addition to their value as paleorecords, these tree-ring archives will also be applied to the study of a number of economic, social or environmental issues. For example, recent drought reconstructions indicate that the catastrophic cocoliztli epidemics of the Mexican Highlands beginning in 1545 and 1576 coincided with the most severe drought in the last 500 years (Acuna-Soto et al., 2000, Fig. 3). Cocoliztli is now thought to be an indigenous haemorrhagic fever, possibly transmitted by rodent hosts and aggravated by drought conditions. It is hypothesized that drought periods can concentrate and spread infection among the residual rodent population. When climatic conditions ameliorate, the infected rodent population may invade farms and homes to spread the disease agent. Humans infected with cocoliztli often died painfully in as little as 3-4 days. Similar climate forcing was observed during the Hantavirus outbreaks in the south- western US in 1993, but cocoliztli probably was not a Hantavirus and the true disease agent remains unknown. Nevertheless, the $16^{\text {th }}$ century epidemics do seem to have occurred during one of the worst Mexican droughts in the past 500 years, and the epidemics of 1545-8 and 1576-8 each reduced the population of the Mexican Highlands by about $50 \%$. Population recovery was slow and numbers remained well below their $16^{\text {th }}$ century levels until the $20^{\text {th }}$ century.

\section{Climate variability}

Reconstruction of climate variability in low latitudes has been hampered by the lack of suitable annually-resolved proxy climate records. This project attempts to narrow the "latitudinal gap" between the presently available tree-ring chronology networks by (i) expanding existing chronology networks equatorwards for those species known to have annual rings and (ii) by exploring the potential of many new species to yield annual ring series. During the last year we have developed chronologies from sites at the extreme range of Douglas fir (Pseudotsuga menziesii) at $17^{\circ}$ and $55^{\circ} \mathrm{N}$ in Mexico and British Columbia, respectively. Chronologies have also been developed from four new tropical species; Pinus hartwegii growing at 3,600-3,700m on Nevado de Colima volcano, Mexico $\left(20^{\circ} \mathrm{N}\right)$ : Polyl- epis tarapacana at 4,800-4,900m on Volcan Sajama, Bolivia $\left(18^{\circ} \mathrm{S}\right)$ and $4,750 \mathrm{~m}$ on Cerro Granados, Argentina $\left(22^{\circ} 32^{\prime} \mathrm{S}\right)$; Polylepis pepei in the Cordillera Tunari, Bolivia $\left(17^{\circ} \mathrm{S}\right)$ and Prosopis ferox at $3,500 \mathrm{~m}$ in the Humahuaca Valley, Argentina $\left(23^{\circ} \mathrm{S}\right)$. Although ring definition varies between these species they all show promise for the reconstruction of temperature (Polylepis) or precipitation (Pinus and Prosopis). Living specimens of Polylepis and Prosopis are known to reach ca. 500 years of age. The two Bolivian chronologies are the highest elevation tree-ring chronologies in the world.

\section{Future goals}

Expanding scientific capacity, training and exchanges are also major goals of the project. New laboratories have been established for basic dendrochronological work in Durango, Mexico, La Paz, Bolivia (both October 2000) and Piura, Peru (January 2001, using IAI-PESCA funding). All will serve regions with little or no prior expertise in tree-ring studies. Dedicated staff are now employed at each facility and have undertaken training at one of the laboratories in the CRN (Mendoza, Tucson, Lamont or Arkansas). The CRN sponsored participation of latin american students in the first dendroecological field courses to be held in Latin America at San Martin de los Andes, Argentina (April 2000); Saltillo, Mexico (August 2001) and in Valdivia, Chile (April 2001).

This project will run in its present form for 5 years and we are still in the initial stages. It will provide new proxy records of local and regional climate variability and change, many from regions that hitherto have been data-poor. It will also be able to generate related datasets (e.g. drought and flow frequencies; estimates of timber production) that may be usefully applied to impact assessment or scenario development for environments undergoing significant climate change. The combination of such regional data sets with other, presently available, data (e.g. from the western United States) will ul- 
timately allow the development of hemispheric-scale datasets for the last 300-500 years. These data sets will be used to document the large spatial and temporal variance that characterises the tropical (ENSO) and high latitude (e.g. PDO) atmospheric circulation features associated with interannual to decadal variability of climate over the Americas. For example, the recent ENSO reconstruction developed by Stahle et al. (1998) may be significantly enhanced by the incorporation of data from drought-resistant and $\mathrm{El}$ Niño sensitive tree-ring chronologies in Central Chile and adjacent Argentina. Similarly the development and combination of data sets to address low frequency climate variability (e.g. Villalba et al, 2001) could significantly improve understanding of phenomena such as the PDO and the relationship between PDO and ENSO phenomena. As the project continues we hope to provide data that will address these large scale issues.

Further information about participating scientists and institutions, plus the first two annual reports of activity and other information can be found on the project's web site at http://www.cricyt.edu.ar/IAl/ or through http://wdc.cricyt.edu.ar/

\section{AcKnowledgements}

We would like to thank R. Villalba, M. Morales and D.W. Stahle for providing the data in Figures 2 and 3, respectively.

\section{REFERENCES}

Acuna-Soto, R., L. Calderon Romero, and J.H. McGuire, 2000. Large epidemics of hemorrhagic fevers in Mexico 1545-1815. American Journal of Tropical Medicine and Hygiene 62(6):733-739.

Acuna-Soto, R., D.W. Stahle, M.K. Cleaveland, M.D. Therrell, in press. Megadrought and megadeath in 16th century Mexico. Emerging Infectious Diseases.

Stahle, D.W., D'Arrigo, R.D., Krusic, P.J., Cleaveland M.K., Cook, E.R., Allan, R.J., Cole, J.E., Dunbar, R.B., Therrell, M.D., Gay, D.A., Moore, M.D. Stokes,. M.A., Burns, B,T, Villanueva-Diaz, J. and Thompson, L.G., 1998. Experimental dendroclimatic reconstruction of the southern oscillation. Bulletin of the American Meteorological Society, 79(10): 2137-2152.

Villalba, R., D’Arrigo, R.D., Cook, E.R., Wiles, G, and Jacoby G.C. 2001. Decadal-scale climatic variability along the extratropical western coast of the Americas: Evidences from tree-ring records. In: Inter-Hemispheric Climate Linkages, Vera Markgraf (ed.), Academic Press. pp. 155-172.

\section{Paleoecology of Eastern Africa Mountains}

\section{Daniel 0. Olago and Eric 0. Odada}

Department of Geology, University of Nairobi, PO Box 30197 Nairobi, Kenya; dolago@uonbi.ac.ke, eodada@uonbi.ac.ke

Africa is a rich repository of paleoenvironmental and paleoclimatic information. It is unique in that it is the only continent that, almost symetrically, straddles the equator, and hence experiences both northern and southern hemispheric climatic influences. This, coupled with the influence of the oceans that surround it, results in an intriguing paleo-record that offers the possibility of understanding the links in climate between the high latitudes and the tropics, and inter-hemispheric teleconnections. Sedimentary records from lakes, swamps and mires, ranging in altitude from sea level to over $5,000 \mathrm{~m}$ above sea level (Kilimanjaro, Ruwenzori and Mt. Kenya, Fig.1), and extending from the northern mid-latitudes to the southern mid-latitudes, provide an array of paleo-proxies and a range of sensitivities to the regional and global climate system that are essential for the elucidation of natural climate and environmental variability in the past. Further data is particularly required in the tropical regions, where a dearth of information exists as compared to the high latitude areas. In particular, most records of the continental tropics do not extend beyond $40,000{ }^{14} \mathrm{C}-\mathrm{yr}$ BP

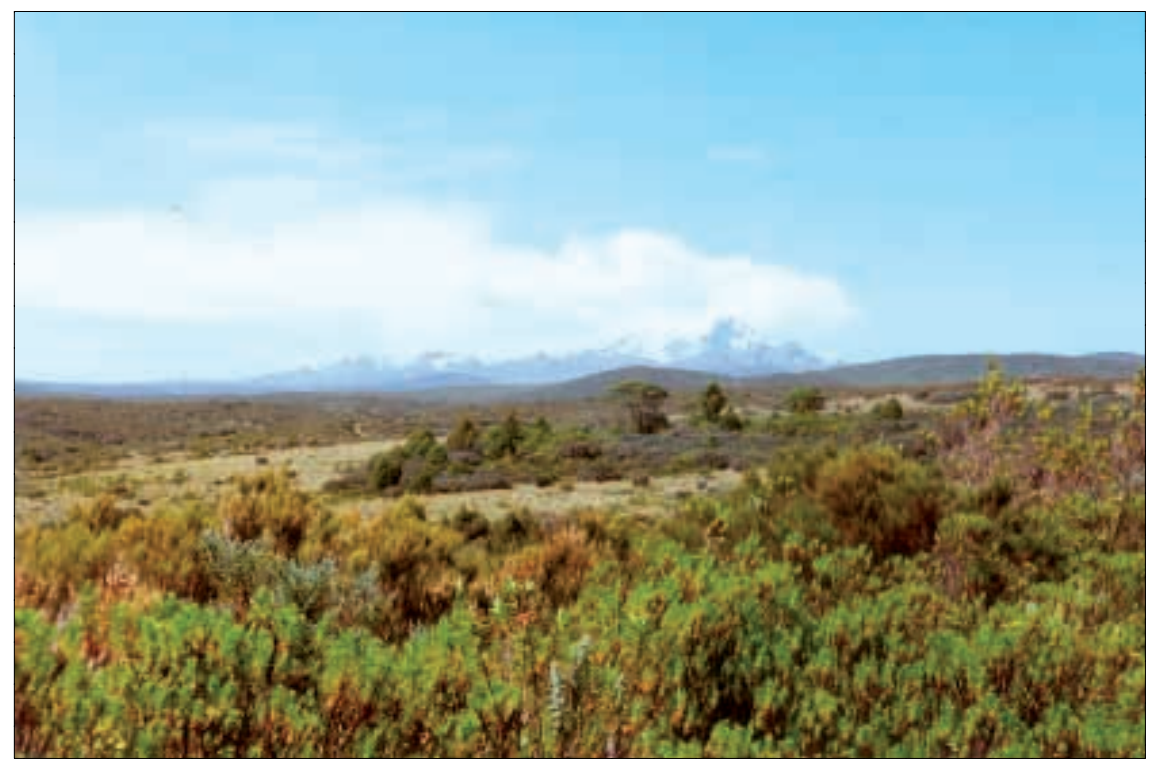

Fig. 1: View of Mount Kenya from the northern moorland.

(most tend to have records less than $\left.30,000{ }^{14} \mathrm{C}-\mathrm{yr} \mathrm{BP}\right)$. In the few cases where a long record exists, poor dating control and consequently poor age models constrain both interpretation, and correlation of events (particularly abrupt events) on local and regional scales.

\section{Modern Vegetation}

The African mountains exhibit high diversity in vegetation types due to the pronounced variations in temperature, atmospheric $\mathrm{CO}_{2}$ con- centration, solar radiation receipts, precipitation and soil moisture indices that are related to the sharp changes in altitude and the effects of topography and aspect. The vegetation is classified into three altitudinal belts, which are, with increasing altitude, the Montane Forest Belt, the Ericaceous Belt and the Afroalpine Belt (Fig. 2). Within the belts, distinct zones are recognised: thus, the Montane Forest Belt contains, in ascending order, the Montane Rain Forest Zone, the Bamboo Zone 


\section{Science Highlights}

and the Hagenia-Hypericum Zone; the Ericaceous Belt contains the Moorland Zone (Fig. 1) and the Ericaceous Zone. The Afroalpine Belt is not divided. Each belt is represented on every mountain (provided it is sufficiently high) but not all the individual zones are necessarily present. There are striking variations in the altitudes of the zone boundaries on different mountains and even on different parts of the same mountain. Some of these differences may be related to the variations in cloud cover, moisture availability and aspect. On Mount Elgon, for example, it appears that under dry sunny conditions, vegetation belts reach higher altitudes on eastern than on western slopes, resulting in considerable differences in the altitudinal ranges of vegetation between the wet and dry sides (Hamilton, 1972). Disturbance often lowers the upper limit of a species, and this is particularly apparent on Mount Elgon, where the upper boundary of the Montane Forest Belt has been lowered, thus reducing the altitudinal range of the forest species (Hamilton, 1972). The upper limit of a species range is more closely determined by temperature conditions than the lower, and extension is greatest in areas of more favourable water balance. In the case of lower altitudinal limits of species ranges, extension is encouraged by one or both of two factors: reduced competition and more favourable moisture conditions. Conditions of reduced competition occur both artificially (forest clearings, grazed land) and naturally (forest gaps, unstable soils, unfavourable microclimates). The high altitude regions $(>2,000 \mathrm{~m}$ a.s.l.) of East Africa are characterised by $\mathrm{C}_{3}$ grasses, and above $4,000 \mathrm{~m}$ grasses are exclusively $\mathrm{C}_{3}$, while lower altitude regions $(<2,000 \mathrm{~m})$ are dominated by $\mathrm{C}_{4}$ grasses but support about $10 \% \mathrm{C}_{3}$ species. It has, however, been shown that there are significant amounts of $\mathrm{C}_{4}$ grasses at altitudes up to $3,200 \mathrm{~m}$ on Mount Kenya, and in some select areas $\mathrm{C}_{4}$ grasses (e.g. Andropogon amethystinus) are found up to $4,000 \mathrm{~m}$.

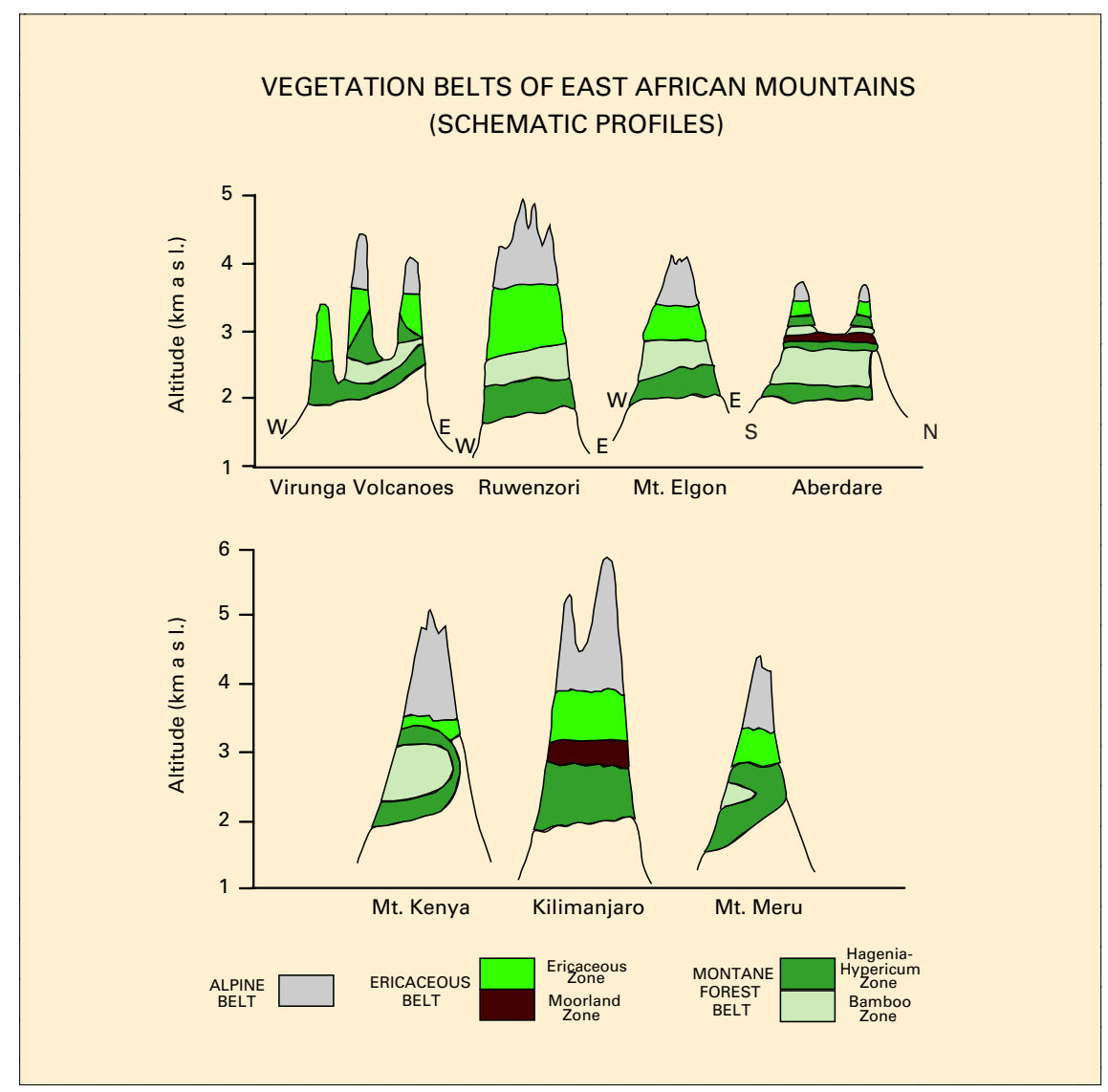

Fig. 2: Schematic profiles of the vegetation belts on East African mountains.

\section{Paleoecology}

The eastern Africa mountains have several swamps and small lakes (crater lakes, tarns) from which sedimentary records of late Quaternary paleoecology have been reconstructed. In this article, we review evidence of the last glacial maximum and Holocene paleoecology of eastern Africa mountains.

The period 22,000 to 14,000 ${ }^{14} \mathrm{C}$-yr BP was characterized by expansion of $\mathrm{C}_{4}$ grassland, the fragmentation and depression of high altitude vegetation zones, and progressive aridity (Fig. 3). Although some differences, due to the local or regional climatic factors peculiar to each area, are observed in the precise timing (real or an artefact of age modeling) of vegetation changes between mountains, the shifts were broadly synchronous. These changes are in turn similar to those that occurred simultaneously across the global low latitude belts, suggesting that these environmental changes were driven by globally pervasive climatic factors. Pollenderived estimates of the temperature depression during the Last Glacial Maximum (LGM) for various tropical sites average about $6^{\circ} \mathrm{C}$. More recent temperature estimates, derived from multivariate statistical analysis of pollen assemblages from Kashiru Swamp, and low-altitude Lake Tanganyika, indicate a decrease of $4^{\circ} \mathrm{C} \pm 2^{\circ} \mathrm{C}$ and $4.2 \pm 3.6^{\circ} \mathrm{C}$, respectively. These estimates are generally lower than the earlier inferred LGM-values for East Africa, but are more plausible in view of the uncertainty of both the influence of the large changes in atmospheric $\mathrm{CO}_{2}$ concentrations in tropical vegetation dynamics and the variability of tropical precipitation on seasonal, inter-annual and decadal time-scales. From water balance studies, LGM precipitation is estimated to have been 9 to $32 \%$ lower than present. A recent polleninferred estimate for LGM precipitation decrease relative to present for the central East Africa highlands is $32 \%$ with two maxima at $19,000{ }^{14} \mathrm{C}-\mathrm{yr} \mathrm{BP}(45 \%)$ and 18,000 to $16,000{ }^{14} \mathrm{C}-\mathrm{yr} \mathrm{BP}(42 \%)$. 


\section{Science Highlights}

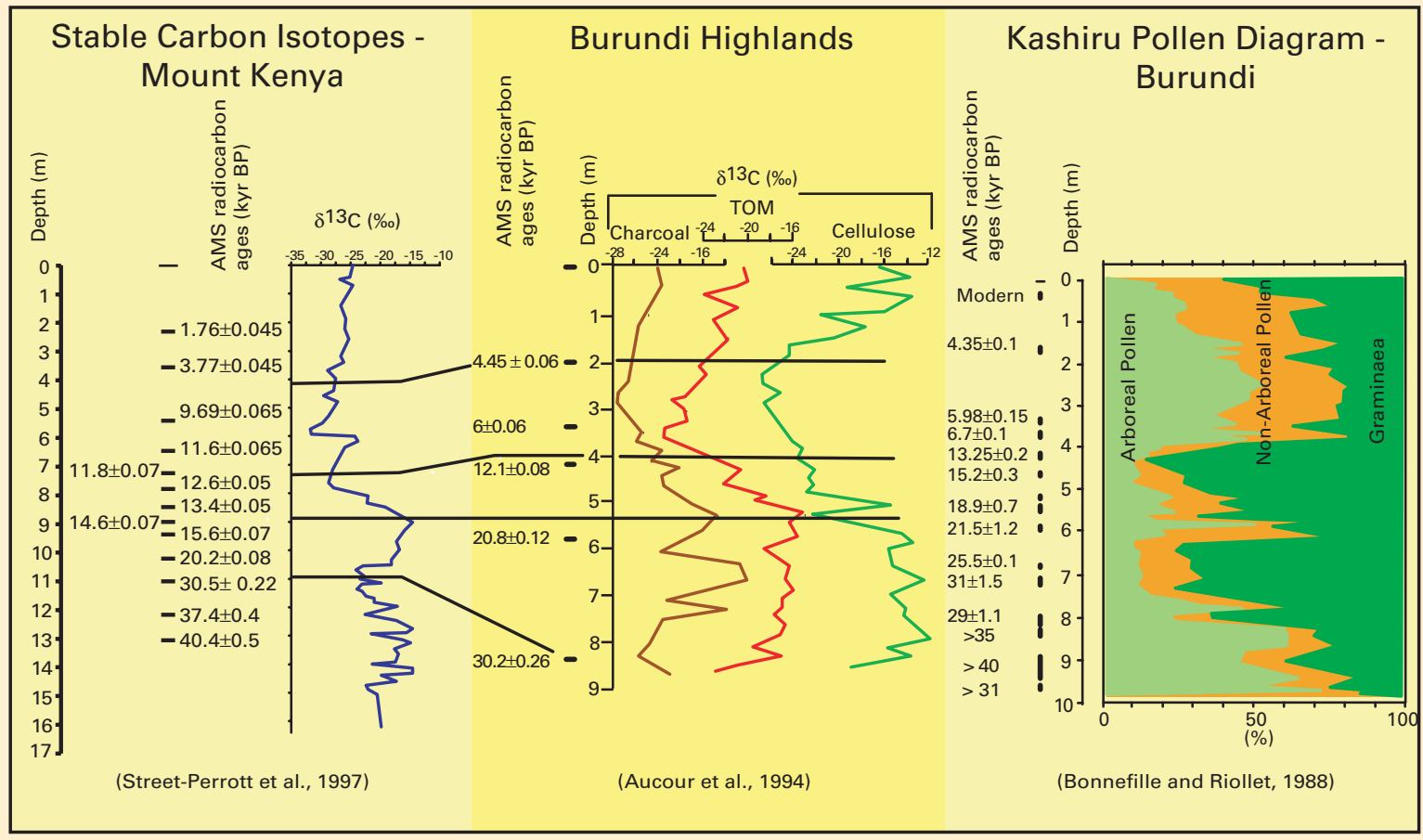

Fig. 3: Profile of glacial-interglacial change from pollen and stable isotope records in east African mountains and highlands.

Pollen, stable carbon isotope data (distinct increase of $\mathrm{C}_{3}$ plants) and morainic evidence show that the period 15,000 to $10,000{ }^{14} \mathrm{C}-\mathrm{yr}$ $\mathrm{BP}$ marked a time of climatic transition, with rising temperatures and an increasingly moist climate. At most sites, increases in $\mathrm{C}_{3}$ plants, marking the onset of warmer, moister climate precede similar evidence from pollen data, and probably reflect a more rapid response of grasses (as compared to woody vegetation) to climatic amelioration. Evidence of a Younger Dryas event is found at some sites, such as on Mount Kenya, between 11,000 and $10,000{ }^{14} \mathrm{C}$-yr BP.

Between 10,000 and $8,000{ }^{14} \mathrm{C}$ yr BP, pollen data indicate a significant expansion of montane forest at high altitude sites occupied by Ericaceous Belt taxa during the last glacial and suggest warmer climate and significantly increased precipitation. Other tropical forests achieved their maximum extension during this period as well. The lake regression phase between 8,000 and $6,000{ }^{14} \mathrm{C}$-yr BP in eastern Africa can be correlated with: 1) relatively cool conditions, depression of the treeline and the establishment of Afroalpine grassland on
Mount Kenya; 2) a shift from evergreen to semi-deciduous forest between 7,000 and 6,000 ${ }^{14} \mathrm{C}-\mathrm{yr}$ BP in the Pilkington Bay area; and 3) an increase in dry tree taxa and Chenoams in the Naivasha area.

Drier conditions in the Holocene were initiated at about $4,000{ }^{14} \mathrm{C}-\mathrm{yr}$ $\mathrm{BP}$. This is reflected by replacement of wet montane forest taxa by dry montane forest taxa and a rise in the savanna-forest ecotone at high altitude sites; a shift towards more positive stable carbon isotope values in lake/swamp sediments; and replacement of trees by herbaceous elements at lower altitudes.

Due to their high environmental and climatic sensitivity, mountains offer particularly good sites for highresolution reconstruction of paleoecological change and elucidation of the factors driving the change. High-resolution, multi-proxy analyses of well-dated cores are particularly required from the tropics to better understand the long- and short-term periodicities that characterise the climate and environment of the region. The African region is today very vulnerable to climatic change. Given the rapidity of human impact on the environment, and the associated uncertainties re- garding the impact on global climate and environment, as well as the modes of feedback and degree of interaction between the various components/factors of change, there is a need to better understand the natural climate and environmental variability. More long-term records of change are therefore required to assess the significance of historically documented and modern-day change in the region. For example, the mechanisms underlying the abrupt, large-scale climatic events in the Holocene need to be understood as they occurred during a period with similar climatic conditions as today.

\section{REFERENCES}

Aucour, A., Hillaire-Marcel, L. C. and Bonnefille, R. 1994, Late Quaternary biomass changes from ${ }^{13} \mathrm{C}$ measurements in a highland peatbog from equatorial Africa (Burundi), Quat. Res., 41: 225-233.

Bonnefille, R. and Riollet, G., 1988, The Kashiru pollen sequence (Burundi) paleoclimatic implications for the last 40,000 yr B.P. in Tropical Africa. Quat. Res., 30: 19-35.

Hamilton, A.C., 1972. The interpretation of pollen diagrams from Highland Uganda, Paleoecol. Afr., 7: 45-149.

Street-Perrott, F.A., Huang, Y., Perrott, R.A., Eglinton, G., Barker, P., Khelifa, L., Harkness, D.D. and Olag, D.0., 1997, Impact of lower atmospheric carbon dioxide on tropical mountain ecosystems. Science, Vol. 278, pp.1422-1426. 


\title{
Climate and Environment during the Last Deglaciation and the Holocene in NW Russia and around the Baltic
}

\author{
St. Petersburg, Russia, 27 March - 2 April, 2001
}

In a beautiful old palace on the southern shore of the Gulf of Finland, researchers from Sweden, Finland, Denmark, Estonia and Russia presented the results of their scientific network project. The Nordic Council of Ministers (www.norden.org) provided funding, enabling the participation of a number of Russian, Swedish and Finnish Ph.D. students and the workshop was organized by the Institute of Limnology, Russian Academy of Sciences, St. Petersburg, together with Lund University, Sweden, and Helsinki University, Finland. More than 60 participants from the UK, Norway, Sweden, Finland, Estonia and Russia took part in the meeting, which was divided into three oral sessions and several poster sessions.

The network project started in 1996, with the objective of using lake sediment analyses to reconstruct environmental changes in NW Russia during the last 15,000 years. The project is mainly financed by the Swedish Institute, the Royal Swedish Academy of Science and the Swedish Natural Science Research Council. Lake sediments were retrieved along a NW-SE transect in regions such as the Kola Peninsula, eastern Russian Karelia, the Karelian Isthmus, the Valdai hills and the Rostov-Jaroslavl' area north of Moscow. To summarize the research results which have been obtained so far, and to compare them with other ongoing research projects, the workshop addressed two major themes: (1) Late Quaternary environmental and climatic changes in NW Russia and around the Baltic Sea, and (2) Baltic Sea development.

J. Lowe (UK) explained the initiatives and proposals of the INTIMATE group (INTegration of Ice-core, MArine and TErrestrial records, www.geog.uu.nl/fg/ paleoclimate/intimate) and discussed how a close collaboration between the NW Russian science

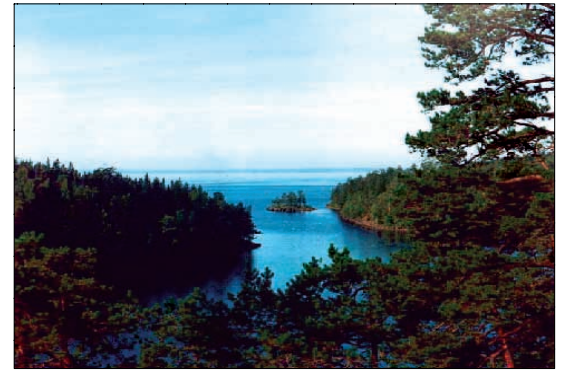

View of Lake Ladoga from the Valaam Island

communities and the INTIMATE project group could be of mutual benefit for improving understanding of the rapid environmental changes around the North Atlantic region during the Last Glacial-Interglacial transition. Lake sediment studies have a long tradition in Russia. The Institute of Limnology (Russian Academy of Science, St. Petersburg) has been involved in paleolimnological research in many regions of the former Soviet Union since the 1950s. D. Subetto and N. Davydova (Russia) gave a historic overview of the Institute's research program, which has involved the study not only of lakes close to St. Petersburg (Lakes Ladoga, Onega and II'men), but also of lakes on the Kola Peninsula, in the Bol'shezemelskaya tundra, in the Urals, in Kazakhstan, in Kirgizyia, as well as in high mountain areas in the Caucasus, the Pamir, Tien-Shan and Mongolia.

A special session was devoted to the results of the joint SwedishRussian project. B. Wohlfarth gave an overview on the present state of the project, which was followed by individual presentations of some of the scientists involved. It was noted that the application of a multi-proxy approach in studying the different lake sites led to the discovery of the Vedde Ash on the Karelian Isthmus and to a complex regional picture of environmental development during the deglaciation and early Holocene.

An attempt to understand the timing of the Littorina transgressions in the southern Baltic
Sea included presentations of ongoing paleoecological studies in Ingermanland, NW Russia. In this area, Littorina transgression phases $(8,000-4,000 \mathrm{BP})$ are being studied and the timing and significance of the observed phases are beingcompared to the south-western and southern Baltic (Själland in Denmark and Blekinge in Sweden). The importance of a uniform sampling strategy and analytical methodology was emphasized.

This very successful meeting, which would not have been possible without the help of the staff and Ph.D. students from the Institute of Limnology and students from St. Petersburg State University (T. Sapelko, D. Kuznetsov, O. Vinogradova, D. Maksimov, A. Maksimova, E. Sikatskaya), certainly helped to establish many new contacts to bridge the gap between Russian and Scandinavian science. Hopefully, young students will now take advantage of these contacts, so that a student exchange programme can gradually be built up. Special thanks go to S. Slotina for organizing the cultural highlights, for professional guidance in St. Petersburg and for help and assistance throughout the conference.

An abstract volume of the lectures and posters is available from the Institute of Limnology, RAS, St. Petersburg.

\section{Dmitry Subetro}

Institute of Limnology, Academy of Sciences St.Petersburg, Russia Subetto@ds5544.spb.edu

\section{Barbara Wohlfarth}

Dept. of Quaternary Geology, Lund University, Lund, Sweden Barbara.Wohlfarth@geol.lu.se

\section{HANNU HyväRINEN \\ Dept. of Geology, Helsinki University Helsinki, Finland Hannu.Hyvarinen@helsinki.fi}




\section{Workshop Reports}

\section{Past Climate Variability Through Europe and Africa}

Aix-en-Provence, France, 27-31 August, 2001

This synthesis conference presented the state of the art in our understanding of past climate variability and its impacts along the PEPIII transect. The 34 plenary overview talks were organized by region and timescale, with more than 200 posters covering detailed regional studies.

The conference started with a bang when David Battisti, in the first plenary presentation, told the audience that the overturning circulation in the modern North Atlantic has only a modest effect on the climate of Europe, and even less impact elsewhere. He followed up with modeling results suggesting that although the THC may set the timescale of late glacial millennial climate variability, a trigger should probably be sought in the tropics.

The role of the tropics in forcing extra-tropical millennial scale variability came up again whenTim Partridge showed a $\sim 200,000$ year long record from the Tswaing impact crater in South Africa. This record shows a strong precessional signal of variability with a period around 40,000 years prior to about $50 \mathrm{kyr}$

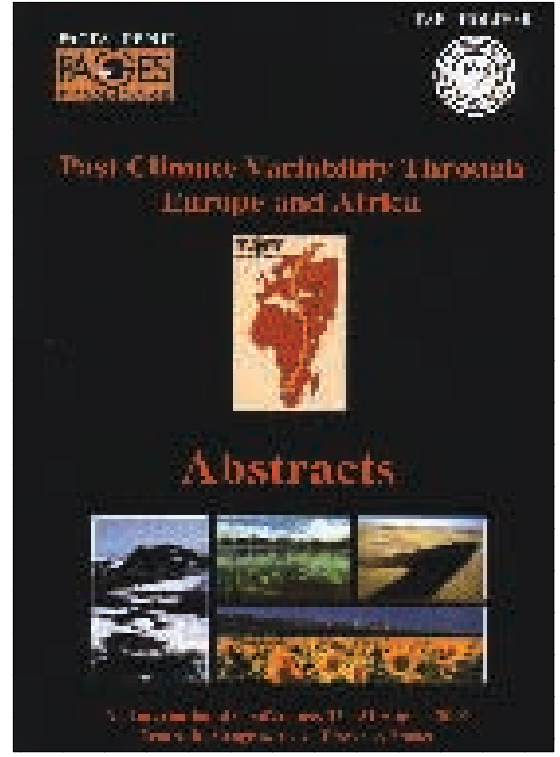

BP. As might be expected based on the insolation forcing, continental African records appear to be antiphase on precessional timescales. Only after 50 kyr BP does the Tswaing record begin to resemble the millennial scale variability seen in Greenland. A regional aridity index suggests that the onset of dry periods in Southern Africa may correlate with Heinrich events, but if so, precede them by 3,000 years.
The range of topics included monsoons, ENSO, solar activity, alpine glacier and treeline variations and athropogenic effects. In the discussions of the future of PEP3, independent dating and understanding the processes which produce local proxy records, were stressed as absolute requirements to address questions of climatic variability on the scale of the transect as a whole. A major future goal for PEP3 was seen to be providing a long term perspective on resource use and sustainability.

With close to 300 participants, this conference was a huge success, thanks to Francoise Gasse, her "on site" team and to Rick Battarbee and Catherine Stickley in London. One outcome will be a synthesis book edited by Rick Battarbee and Francoise Gasse entitled "Past Climate Variability Through Europe and Africa." This book will be available from Kluwer in 2002.

Keith Alverson and Isabelle Larocaue PAGES IPO, Berne, Switzerland, alverson@pages.unibe.ch, larocque@pages.unibe.ch

\section{Have you seen:}

\section{$A$ new book on the PAGES boolsh helf: \\ "GLLAGERS AND CLIMAVIE CHANGE"' \\ Johannes Oerlemans \\ published by A.A. Balkema Publishers / Lisse / Abingdon /Exton / Tokyo 2001}

\section{Content:}

- Introduction

- Basic concepts

- The micro-climate of a valley glacier

- Modeling glacier mass balance

- Modeling the geometry and flow of a valley glacier

- Calculations for a glacier of constant width

- More realistic geometry

- Numerical modeling of real glaciers

- Climatic interpretation of glacier fluctuations

- The global picture and sea level rise

- The future of glaciers

- The future of glacier research

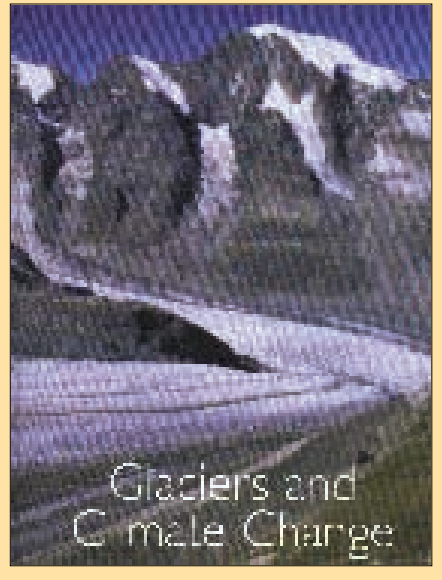




\section{Last PA(3E}

\section{- Calendar}

February, 10 - 15, 2002, Ascona, Switzerland: Conference on Coccolithophores

May, 16 - 17, 2002, Moscow:

Further information:

Dr. Patrick Sean Quinn, patrick.quinn@erdw.ethz.ch

http://www.coccoco.ethz.ch/

PAGES SSC meeting and Workshop on "High Latitude Paleoenvironments"

Further information:

Isabelle Larocque, laroque@pages.unibe.ch

http://www.pages-igbp.org

March, 18 - 22, 2002, Lepizig, Germany:

First Workshop of the DEKLIM-EEM project: Climate

June, 13 - 16, St. Cloud, MN, USA:

Change at the Very End of a Warmstage

Further information:

Saskia Rudert, rudert@mail.uni-mainz.de

http://www.uni-mainz.de/FB/Geo/Geologie/sedi/index.html

March, 25 - 27, Springfield, USA, 2002:

Holocene Climate and Lakes

The 2nd International Past Grasslands Research Conference (PGR 2002)

Further information:

Dr. Andrea Lini, alini@zoo.uvm.edu

http://www.geosociety.org/sectdiv/northe/02nemtg.htm

Further information:

Mikhail Blinnikov, mblinnikov@stcloudstate.edu

http://www.visitstcloudmn.com/pages/visitor.html

July, 15 - 18, 2002, Madrid, Spain:

Quaternary Climatic Changes and Environmental Crises in the Mediterranean region

Further information:

Ana Vadeolmillos Rodriguez, climatic.changes@uah.es

http://www2.uah.es/qchange2002

\section{Several START Young Scientist Awards given to PAGES scientists!}

The 2001 STARTYoung Scientist Award program was the most successful yet. The largest number of very well qualified candidates applied since the awards program was established. In response, the number of awards was expanded this year from 10 to 16.

The PAGES related 2001 STARTYoung Scientist Awardees are:

\section{GuSti Anshari}

Tanjungpura University, Indonesia for his paper, "A late Pleistocene and Holocene pollen and charcoal record from peat swamp forest, Lake Sentarum Wildlife Reserve, West Kalimantan, Indonesia." Paleogeography, Paleoclimatology, Paleoecology (2001) in press. Gusti began his affiliation with PAGES as a grantee to present his work at the Global Change Open Science Conference in Amsterdam, 2001.

\section{Brahim Damnati}

Department of Earth Sciences and Oceanology, Abdelmalek Essaadi University, Tangier, for his paper, “Holocene lake records in the Northern Hemisphere of Africa." Journal of African Earth Sciences (2000) 31(2):253-262. Brahim began his affiliation with PAGES with a fellowship to attend the Swiss Climate Summer School along with a PAGES workshop on outreach to young scientists in developing countries in 1999.

\section{Zewdu Eshetu}

Department of Botany, University of Cape Town, South Africa for his paper, "Reconstruction of forest site history in Ethiopian highlands based on ${ }^{13} \mathrm{C}$ natural abundance of soils." Ambio (2000) 29(2):83-117. Zewdu began his affiliation with PAGES on being awarded a hardbound copy of the PAGES special issue "Past Global Changes and their Significance for the Future" based on his presentation at the Global Change Open Science Conference In Amsterdam.

\section{Thamban Meloth}

Department of Geology, Government College Kasargod, India for his paper, "Glacial to Holocene fluctuations in hydrography and productivity along the southwestern continental margin of India." Paleogeography, Paleoclimatology, Paleoecology (2001) 165:113-127. Thamban began his affiliation with PAGES with a fellowship to attend the Swiss Climate Summer School in 1999. He has continued his interaction with PAGES as one of the authors of the PEP2 Synthesis volume currently in preparation. 